\title{
Interleukin-4 and interleukin-13 increase NADPH oxidase 1-related proliferation of human colon cancer cells
}

\author{
Han Liu ${ }^{1}$, Smitha Antony ${ }^{1}$, Krishnendu Roy ${ }^{1}$, Agnes Juhasz ${ }^{2}$, Yongzhong Wu ${ }^{2}$, Jiamo \\ Lu$^{2}$, Jennifer L. Meitzler ${ }^{2}$, Guojian Jiang ${ }^{2}$, Eric Polley ${ }^{1}$ and James H. Doroshow ${ }^{1,2}$ \\ ${ }^{1}$ Division of Cancer Treatment and Diagnosis, National Cancer Institute, Bethesda, Maryland, USA \\ 2 The Center for Cancer Research, National Cancer Institute, Bethesda, Maryland, USA \\ Correspondence to: James H. Doroshow, email: doroshoj@mail.nih.gov \\ Keywords: NADPH oxidase, reactive oxygen species, colon cancer, interleukin-4, interleukin-13 \\ Received: December 21, $2016 \quad$ Accepted: April 17, $2017 \quad$ Published: April 27, 2017
}

Copyright: Liu et al. This is an open-access article distributed under the terms of the Creative Commons Attribution License (CC-BY), which permits unrestricted use, distribution, and reproduction in any medium, provided the original author and source are credited.

\section{ABSTRACT}

Human colon cancers express higher levels of NADPH oxidase 1 [NOX1] than adjacent normal epithelium. It has been suggested that reactive oxygen species [ROS] derived from NOX1 contribute to DNA damage and neoplastic transformation in the colon, particularly during chronic inflammatory stress. However, the mechanism(s) underlying increased NOX1 expression in malignant tumors or chronic inflammatory states involving the intestine are poorly characterized. We examined the effects of two pro-inflammatory cytokines, IL-4 and IL-13, on the regulation of NOX1. NOX1 expression was increased 4- to 5-fold in a time- and concentration-dependent manner by both cytokines in human colon cancer cell lines when a functional Type II IL-4 receptor was present. Increased NOX1 transcription following IL-4/IL-13 exposure was mediated by JAK1/STAT6 signaling, was associated with a ROS-related inhibition of protein tyrosine phosphatase activity, and was dependent upon activation and specific binding of GATA3 to the NOX1 promoter. NOX1-mediated ROS production increased cell cycle progression through $S$-phase leading to a significant increase in cellular proliferation. Evaluation of twenty pairs of surgically-resected colon cancers and their associated uninvolved adjacent colonic epithelium demonstrated a significant increase in the active form of NOX1, NOX1-L, in tumors compared to normal tissues, and a significant correlation between the expression levels of NOX1 and the Type II IL-4 receptor in tumor and the uninvolved colon. These studies imply that NOX1 expression, mediated by IL-4/IL-13, could contribute to an oxidant milieu capable of supporting the initiation or progression of colonic cancer, suggesting a role for NOX1 as a therapeutic target.

\section{INTRODUCTION}

Although a robust flux of reactive oxygen species [ROS] may produce significant tissue injury [1], low intracellular ROS levels, especially of $\mathrm{H}_{2} \mathrm{O}_{2}$, can play a critical role in signal transduction $[2,3]$, providing essential proliferative signals required for tumor cell growth [4] and angiogenesis [5, 6]. ROS are also strongly associated with pro-inflammatory states that contribute significantly to carcinogenesis and tumor progression $[7,8]$. Our understanding of the mechanisms of ROS formation in tumors has been enhanced during the past decade by the discovery of six NADPH oxidases
[NOX1,3,4, and 5; DUOX1 and 2] in mammalian cells that are structural homologues of gp91 ${ }^{\text {phox }}$ [NOX2], the major membrane-bound component of the respiratory burst oxidase of leukocytes [9-11].

The first of the NOX2 homologues to be described, NOX1, was discovered through study of Caco2 human colon cancer cells [12]; recent experiments have clarified the role of NOX1-mediated ROS production in colon cancer cell migration, integrin signaling, proliferation, and carcinogenesis [13-17]. In addition, while NOX1 appears to contribute to gastrointestinal host defense and wound healing [18-20], there is also evidence that premalignant, chronic inflammation of the colon (in mouse 
models) is associated with functional expression of NOX1 [21]; hence, NOX1 could contribute to the pathogenesis of inflammation-related colonic malignancies. These recent genetic studies are consistent with the demonstration of enhanced NOX1 expression in vitro following exposure of intestinal cancer cells to the pro-inflammatory cytokines interferon- $\gamma[$ IFN- $\gamma]$ and tumor necrosis factor- $\alpha$ [TNF- $\alpha$ ] [22]. Despite the fact that a wide range of inflammatory cytokines has been associated with pre-malignant chronic inflammation of the colon and inflammatory bowel disease [23], gaps exist in our understanding of the regulatory mechanisms (beyond plasma membrane association or phosphorylation of components of the NOX1 complex) $[24,25]$ that control NOX1 expression in the colon, particularly in response to inflammatory stimuli.

Our laboratory recently demonstrated that small molecule inhibitors of NOX1 decrease human colon cancer cell proliferation both in vitro and in human tumor xenografts [17]. Using a bioinformatics approach, we found that the pattern of NOX1 inhibitor-related growth delay across a large human tumor cell line panel (the NCI-60) was significantly related to the expression of inflammation-related genes, including the cytokine interleukin-4 [IL-4] and components of the JAK/ STAT pathway [26]. In support of this hypothesis, we demonstrated that exposure of human colorectal cancer cells to clinically-achievable concentrations of the NOX (and related flavin dehydrogenase) inhibitors diphenylene iodonium [DPI] or 2-di-thienyl-iodonium [DTI], which decreased intracellular ROS levels, blocked IL-4- and IL13-induced phosphorylation of STAT1, 3, and 6, as well as signaling through the mitogen activated protein kinase [MAPK] pathway. These experiments suggested that ROS generated by NOX1 might affect IL-4/IL-13-dependent signal transduction events in colon cancer.

IL-4 and IL-13, produced by activated $\mathrm{T}$ helper type $2\left[\mathrm{~T}_{\mathrm{H}} 2\right]$ lymphocytes and other immune cells, were discovered over 25 years ago [27]; the focus of most investigation since that time has been on the important roles of these cytokines in immuno-surveillance [28], the induction of immunoglobulin switching in B cells and the pathology of asthma [29], as well as macrophage polarization. Recent studies, however, have also emphasized the growth-promoting and prometastatic roles of these cytokines that are often highly expressed intracellularly, as well as in the surrounding microenvironment, in a wide variety of epithelial cancers, including colorectal cancer [30-37]. Binding of IL-4 or IL13 to the Type II IL-4 receptor [IL-4R $\alpha$ ], which is found on non-lymphoid cells, initiates a signaling cascade that activates the JAK/STAT pathway (particularly STAT6) as well as MAPK and Akt cell-survival functions; one biochemical consequence of receptor activation is a context-dependent increase in the expression of antiapoptotic proteins that can contribute to enhanced cell proliferation and resistance to cancer therapy $[38,39]$. IL-
13 may also signal through AP-1-dependent pathways (and the separate IL-13R $\alpha 2$ ), independent of those pathways activated by IL-4, to increase invasion and metastasis [40].

A relationship between reactive oxygen production and IL-4 function was postulated by Sharma and colleagues [41] who suggested that exposure of the A549 human lung adenocarcinoma cell line to IL-4 activated NOX1 to generate ROS within minutes, without changing NOX1 expression levels; they suggested that subsequent, ROS-related inhibition of protein tyrosine phosphatase activity could play an important, enhancing role in IL-4 signaling.

In contrast, the experiments reported herein demonstrate that human colon cancer cell lines significantly increase NOX1 expression (but not that of other NOXs) following 12 to $120 \mathrm{~h}$ of continuous exposure to IL-4 or IL-13; ROS production in these cells is associated with the presence of NOX1 protein at the plasma membrane surface. Furthermore, NOX1-dependent ROS enhance colon cancer proliferation by increasing cell cycle progression through $\mathrm{S}$ phase. Increased NOX1 transcription is directly related to activation of the JAK1/ STAT6 pathway and is mediated by the binding of the GATA3 transcription factor to the NOX1 promoter. Finally, the clinical relevance of these in vitro experiments is supported by our demonstration that the expression of NOX1 at the mRNA level in human colon cancers is significantly correlated with the expression of IL-4R $\alpha$, suggesting that IL-4-dependent NOX1 expression may be a novel therapeutic target in this disease.

\section{RESULTS}

\section{NOX1 expression in human colon cancer cells is increased by IL-4 or IL-13 treatment}

To examine the relationship between exogenous IL-4 or IL-13 exposure and the expression of NOX1, we first determined whether the NOX1-expressing colon cancer cell lines under study possessed IL-4R $\alpha$, as has been reported previously [31]. We confirmed by real time RT-PCR that IL-4R $\alpha$ mRNA is present in all of the human colon cancer cells utilized (Supplementary Figure S1A). When HT-29 cells were treated with IL-4, NOX1 mRNA expression increased in a concentration- and timedependent manner, as early as $12 \mathrm{~h}$ following cytokine exposure, and at IL-4 concentrations as low as $1 \mathrm{ng} / \mathrm{ml}$ $(P<0.01)$ (Figures 1A and 1B). Because NOX1 levels were maximal following exposure to $50 \mathrm{ng} / \mathrm{ml}$ of IL-4 $(\approx$ 4 to 5 -fold increase), that concentration was employed in subsequent experiments. Western analysis revealed that increased NOX1 protein levels correlated with the increase in NOX1 mRNA produced by IL-4 exposure (Figure 1B). Furthermore, expression level changes 
A

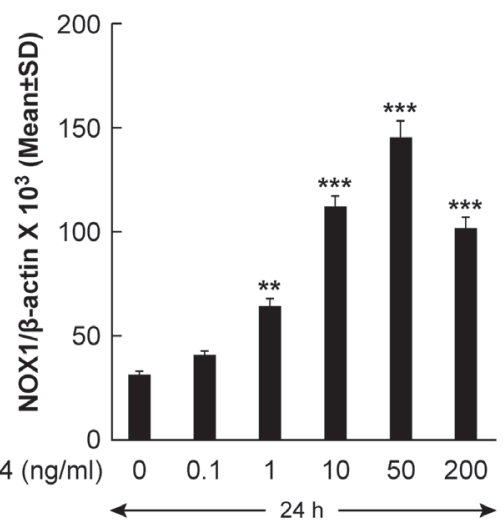

C

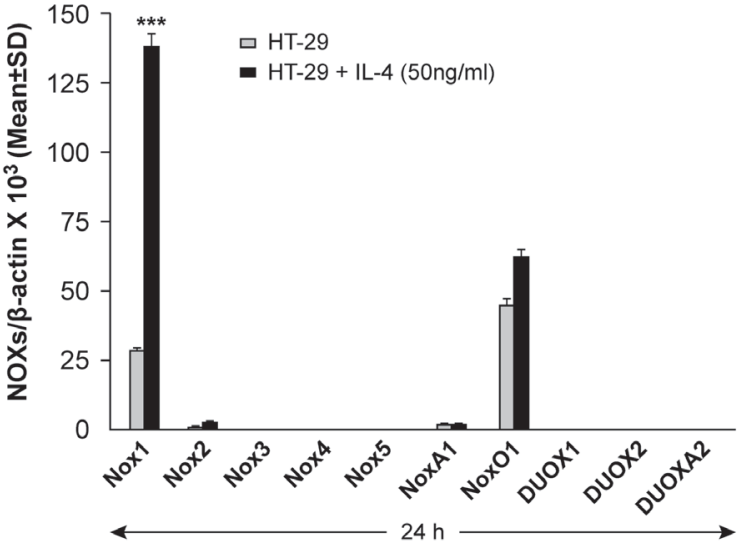

D

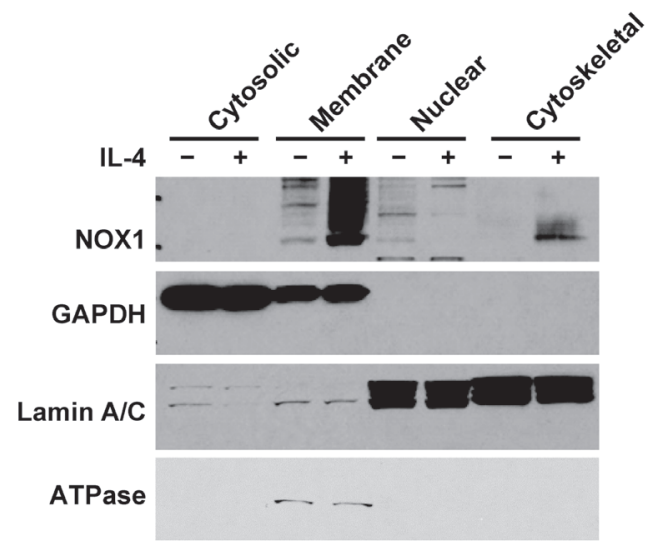

B
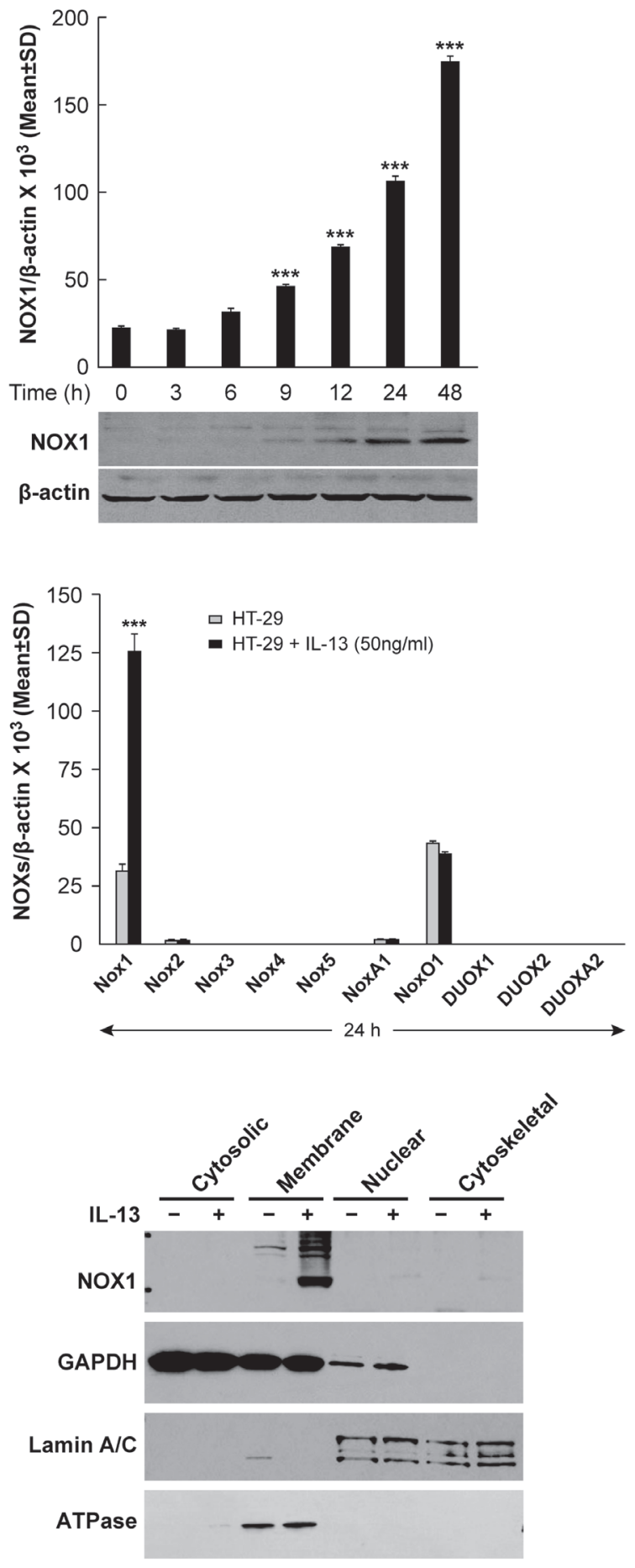

Figure 1: Expression of NOX1 in HT-29 cells following IL-4/IL-13 treatment. A. IL-4 induced a dose-dependent increase in NOX1 expression; HT-29 cells were treated with IL-4 at different concentrations $(0,0.1,1,10,50,200 \mathrm{ng} / \mathrm{ml})$ for $24 \mathrm{~h}$. NOX1 levels were analyzed by quantitative RT-PCR with $\beta$-actin serving as the internal control. B. HT-29 cells were treated with IL-4 (50 ng/ml) for different lengths of time $(0,3,6,9,12,24$, and $48 \mathrm{~h})$; levels of NOX1 expression were determined using quantitative RT-PCR and Western analysis with $\beta$-actin serving as the internal control. C. IL-4 and IL-13 specifically induced the expression of NOX1 but not of other NOX family members. HT-29 cells were treated with IL-4 (left) or IL-13 (right) at a concentration of $50 \mathrm{ng} / \mathrm{ml}$ for $24 \mathrm{~h}$. Quantitative RT-PCR was performed to evaluate the expression levels of the individual NOX family members and their accessory genes; expression levels were normalized to $\beta$-actin. D. NOX1 protein induced by exposure to IL-4 or IL-13 is localized to the plasma membrane. HT-29 cells were treated with IL-4 (left) or IL-13 (right) at a concentration of $50 \mathrm{ng} / \mathrm{ml}$ for $24 \mathrm{~h}$. Western analysis was performed on subcellular fractions (cytosolic, membrane, nuclear and cytoskeletal) to determine the localization of NOX1. GAPDH, ATPase, and Lamin A/C were used as cytosolic, membrane, and nuclear markers, respectively. Data represented as mean $\pm \mathrm{SD}$ values; $* *=P<0.01 ; * * *=P<0.001$. 
following IL-4 treatment were specific for NOX1; none of the other members of the NOX family, nor the accessory genes associated with NOX activity, demonstrated a similar pattern of response following the addition of IL-4 to HT-29 cells (Figure 1C). In concert with these results, we found that IL-4 increased NOX1 expression in other colon cancer lines, including DLD-1, WiDr, NCI-H508, and SW403 cells (Supplementary Figure S1B). Because IL-4 and IL-13 are functionally related and share the Type II IL-4R [42, 43], we also evaluated the response of HT-29 cells to IL-13; as expected, IL-13 specifically increased the expression of NOX1 (Figure 1C). Furthermore, we found that the expression of NOX1 was also increased by IL-13 in DLD-1, WiDr, NCI-H508, and SW403 cells (Supplementary Figure S1B). Because functional NOX1 protein exists as a multi-component plasma membrane complex [44], subcellular fractionation studies were performed to determine the localization of NOX1 protein following IL-4 or IL-13 exposure. Cytokine-enhanced NOX1 protein expression co-purified with the plasma membrane marker $\mathrm{Na}^{+} / \mathrm{K}^{+}$ATPase, demonstrating the plasma membrane localization of the NOX1 that had been expressed (Figure 1D). Similar experiments utilizing IL4-treated DLD-1 colon cancer cells confirmed the plasma membrane location of the NOX1 that had been produced (Supplementary Figure S1C). We also found for DLD-1 cells that the effect of IL-4 exposure on NOX1 expression was time-dependent (Supplementary Figure S1D).

\section{Increased NOX1 expression and ROS production following cytokine exposure significantly enhance the proliferation of colon cancer cells}

We recently reported that stable knockdown of NOX1 in HT-29 colon cancer cells (clone 6A with > $90 \%$ inhibition of NOX 1 ; and clone Si6/G6 with $\approx 65 \%$ NOX1 knockdown) significantly decreases ROS formation compared to cells carrying a scrambled NOX1 shRNA (SC cells) or the parental line [16]. As demonstrated in Figure 2A, IL-4 exposure $(50 \mathrm{ng} / \mathrm{ml})$ for $24 \mathrm{~h}$ increased NOX1 protein expression in both parental HT-29 cells and scrambled shRNA control cells but had modest to no effect on NOX1 knockdown clonal lines, whether or not IL-4 exposure was performed in the presence or absence of $10 \%$ serum. Using a chemiluminescent probe to detect phorbol myristate acetate [PMA]-induced NOX1 activity, we found that treatment with IL-4 $(50 \mathrm{ng} / \mathrm{ml})$ for $24 \mathrm{~h}$ significantly increased ROS generation in both SC cells and the parental HT-29 line $(P<0.001)$; ROS formation in these two control cell lines was completely eliminated by treatment with superoxide dismutase [SOD] (Figure 2B). However, as was the case for NOX1 protein expression, NOX1 activity (ROS production) was not significantly increased following incubation with IL-4 for the $6 \mathrm{~A}$ NOX1 knockdown cells; ROS production for the
IL-4-treated Si6/G6 cells (that exhibit a lesser degree of NOX1 knockdown) was increased over control levels but much less so than scrambled controls or the parental line (Figure 2B). To confirm these results, we utilized a second measure of intracellular ROS production, the conversion of the non-fluorescent probe 2',7'-dichlorodihydrofluorescein diacetate $\left(\mathrm{H}_{2}\right.$-DCFDA $)$ to the fluorescent moiety dichlorofluorescein (DCF) which can be measured by analytical cytometry [45]. We found that IL-4 treatment of parental HT-29 cells for $96 \mathrm{~h}$ produced a substantial right shift (increase) in green fluorescence consistent with increased ROS production; pre-incubation of HT-29 cells with the flavin dehydrogenase (and NOX) inhibitor DPI decreased ROS production (Figure 2C). In related experiments under identical conditions, other than for the use of a $48 \mathrm{~h}$ rather than a $96 \mathrm{~h}$ cytokine treatment time, exposure of HT-29 cells to IL-13 rather than IL-4 produced a very similar right shift in DCF fluorescence (data not shown). However, when HT-29 cells were treated with IL-4 (50 ng/ml) for $5 \mathrm{~min}$ (rather than $96 \mathrm{~h}$ ), we could not demonstrate an increase in DCF fluorescence compared to colon cancer cells exposed to medium alone (Figure 2C).

Because stable NOX1 knockdown in HT-29 cells significantly decreases tumor cell proliferation [16], we examined the effect of IL-4 exposure on the growth of parental HT-29 cells and NOX1 knockdown clonal variants. Concordant with the effect of IL-4 on NOX1 expression and ROS production in these cell lines, IL-4 exposure significantly increased tumor cell proliferation in both parental HT-29 and scrambled shRNA control cells over a $96 \mathrm{~h}$ period of observation $(P<0.001)$, and modestly increased proliferation in Si6/G6 cells (Figure 2D). On the other hand, IL-4 produced no effect on the growth of $6 \mathrm{~A}$ cells which possess minimal NOX1 protein (Figures 2D and 2E). Furthermore, treatment for $48 \mathrm{~h}$ with IL-4 did not affect the growth of CCD-112 normal colon cells that do not express NOX1 (data not shown). We also examined the level of IL-4R $\alpha$ mRNA and protein in our panel of HT-29 cells to exclude the possibility that clonal selection might have altered receptor expression (and hence, sensitivity to IL-4); as demonstrated in Figure $2 \mathrm{E}, \mathrm{NOX} 1$ knockdown had no effect on the expression of the IL-4R $\alpha$ in our control HT-29 cells as well as HT-29derived knockdown cells at either the mRNA or protein level.

To gain a better understanding of the kinetics of the IL-4-mediated modulation of NOX1, we also studied the effect of early elimination of IL-4 from the tissue culture medium on NOX1 expression and HT-29 cell proliferation (Supplementary Figure S2). When IL-4 was removed from the medium after $24 \mathrm{~h}$, NOX1 expression continued to increase for another $24 \mathrm{~h}$, but subsequently declined steadily with an approximate half-time of $48 \mathrm{~h}$; however, $96 \mathrm{~h}$ following removal of IL-4, the NOX1 expression level was still above baseline. The decrease in NOX1 
A

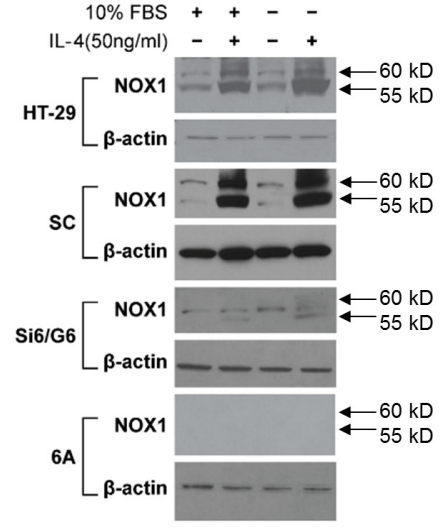

C

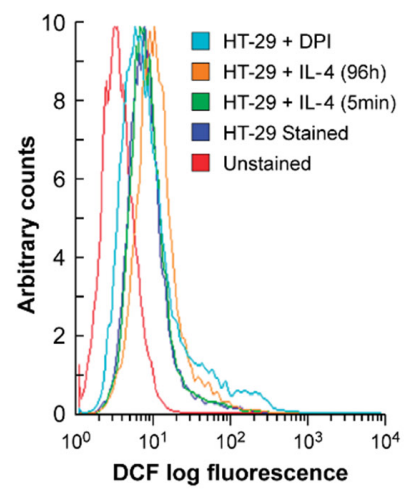

D

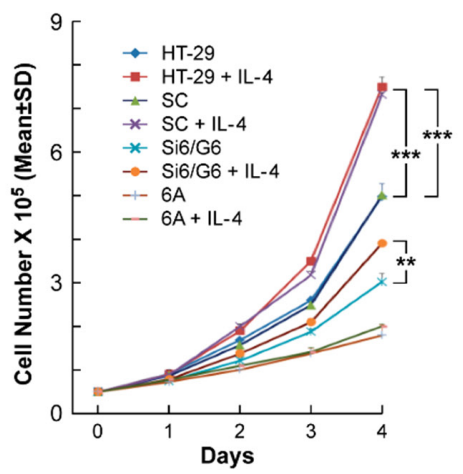

B
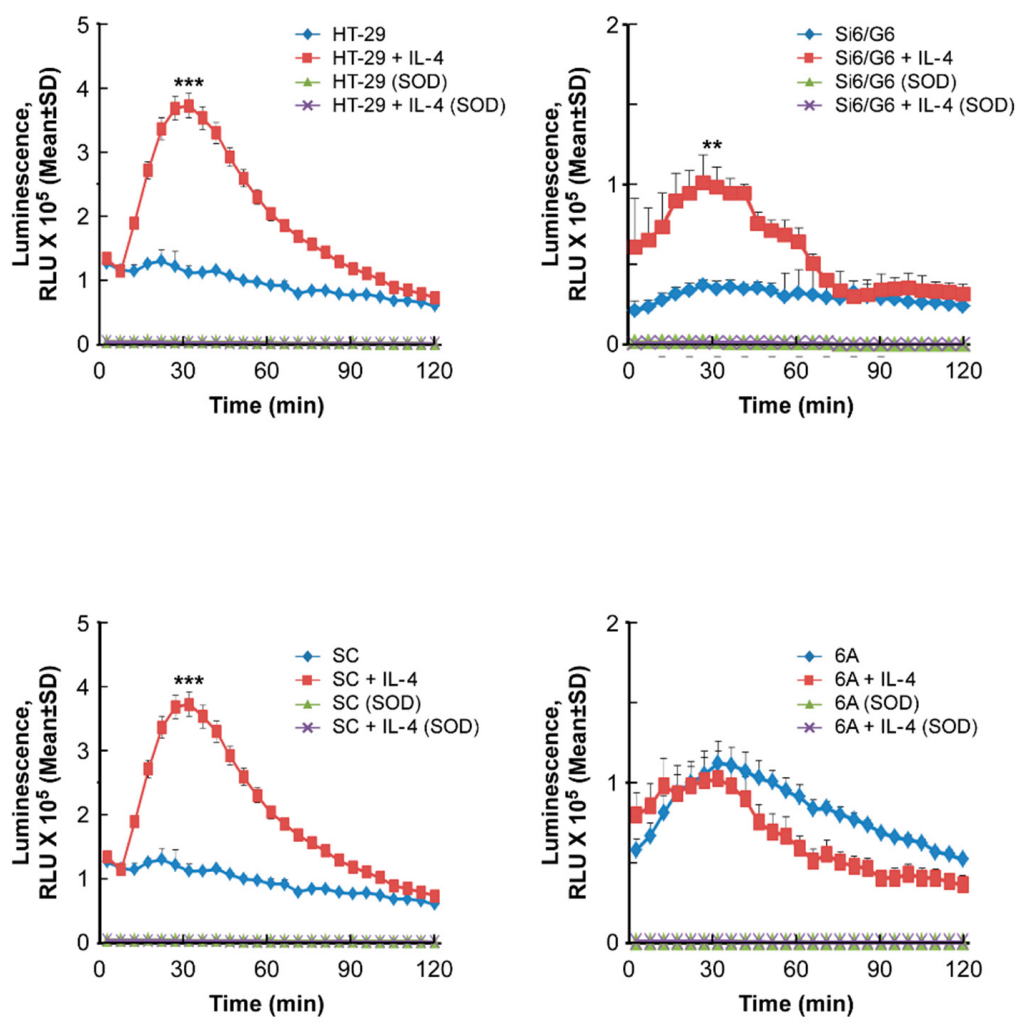

$\mathbf{E}$
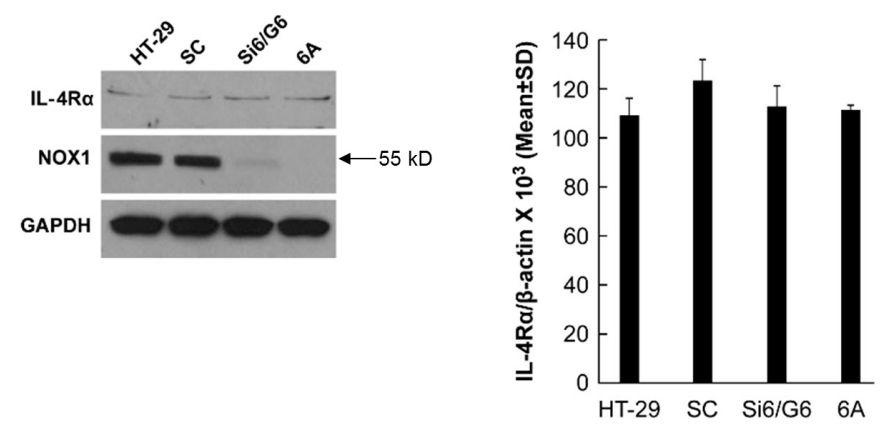

Figure 2: Effect of IL-4 on NOX1 protein expression, ROS production, and cell proliferation in HT-29 cells. A. The effect of IL-4 on the protein expression of NOX1 is demonstrated by Western analysis under both serum-free conditions and in the presence of $10 \%$ FBS for both parental HT-29 cells and a clonal line selected for expression of a scrambled shRNA (SC cells). Modest to no effect of IL-4 on NOX1 expression is shown for the Si6/G6 intermediate NOX1 knockdown clones, or for 6A cells ( $>90 \%$ NOX1 knockdown), respectively. B. NOX1 protein levels correlate with relative superoxide production following IL-4 exposure. Compared to superoxide production in HT-29 and SC cells exposed to IL-4, superoxide levels were only modestly increased in Si6/G6 cells, and were not changed at all by IL-4 treatment in 6A cells. C. IL-4 treatment increases ROS production in HT-29 cells. HT-29 cells were treated with IL-4 for the indicated times, harvested, and stained with $\mathrm{CM}-\mathrm{H}_{2}$-DCFDA. Flow cytometry was performed to evaluate intracellular ROS levels. Compared with parental HT-29 cells, exposure to IL-4 for $96 \mathrm{~h}$ shifted intracellular fluorescence intensity to the right, indicating higher ROS levels; treatment with IL-4 for 5 min, however, produced no shift in DCF fluorescence. Pretreatment with the flavin dehydrogenase and NOX inhibitor DPI produced a left shift in fluorescence intensity. D. IL-4 $(50 \mathrm{ng} / \mathrm{ml})$ promotes HT-29 and SC cell proliferation. Cell numbers were counted daily in the presence or absence of IL-4 for 4 days. After the 4-day IL-4 treatment, compared with corresponding controls, HT-29 and SA cells showed a nearly 2-fold increase in cell number; the 6A (NOX1 knockdown) cells demonstrated lower levels of proliferation in the presence or absence of IL-4; the G6 cells (partial NOXI knockdown) displayed modest growth and modest enhancement of proliferation in the presence of IL-4. E. IL-4R expression is independent of NOX1 expression. Irrespective of NOX1 status, there was no significant change in IL-4R $\alpha$ expression as measured by Western analysis (left panel) or quantitative RT-PCR (right panel). GAPDH and $\beta$-actin served as the internal controls, respectively. Data represent the mean $\pm \mathrm{SD}$ of at least 3 experiments. $* *=P<0.01 ; * * *=P<0.001$. 
expression over time was mirrored by a decrease in the degree of cytokine-enhanced proliferation compared to continuous IL-4 exposure, albeit at a level that was still higher than in control cells exposed to medium alone. To evaluate the generality of these observations, we also examined the effect of IL-4 exposure on ROS production and tumor cell proliferation in DLD-1 human colon cancer cells (Supplementary Figures S1E and S1F). Increased NOX1 expression produced by IL-4 exposure in the DLD1 line, similar to HT-29 cells, was also associated with an increase in tumor cell growth and the production of ROS.

Because IL-4 exposure has been shown previously to upregulate survivin and to alter the expression of several members of the apoptotic pathway [38, 39, 46], we evaluated whether IL-4-mediated changes in the apoptotic cascade might explain the enhanced proliferation rate we observed for HT-29 cells. We found, however, that exposure of HT-29 cells to IL-4 for either 24 or $96 \mathrm{~h}$ did not affect the expression of Bcl-2 or alter the integrity of caspase 3 or 8 (Supplementary Figure S2D).

\section{Functional ROS production by NOX1 is required to enhance colon cancer cell proliferation}

To explore potential mechanism(s) of IL-4-related tumor cell proliferation further, we examined the effect of IL-4 on the expression of the two known isoforms of NOX1, NOX1-L and NOX1-S [47]. Two sets of primers were used to detect these two distinct isoforms; NOX1-L is the full-length, functional form of NOX1, while NOX1-S is a smaller splice variant that lacks an NADPH binding site. RT-PCR analysis demonstrated that IL-4 treatment for $24 \mathrm{~h}$ increased the expression of NOX1-L in HT-29 cells which was associated with a marked increase in PMAinduced ROS formation (Figure 3A and 3B). Transient transfection of HT-29 cells with NOX1-L (Figure 3A) increased ROS production by HT-29 cells $48 \mathrm{~h}$ following transfection to a degree equivalent to that observed following IL-4 treatment (Figure 3B). When the effect of IL-4 exposure on cell cycle progression was examined in HT-29 cells using BrdU labeling and analytical cytometry, treatment with IL-4 for $24 \mathrm{~h}$ significantly increased the fraction of HT-29 cells in S phase (by $>5 \% ; P<0.001$; Figure $3 \mathrm{C}$ ). Consistent with our measurements of reactive oxygen production, transient overexpression of NOX1-L also increased cell cycle traverse through $\mathrm{S}$ phase by $>$ $5 \% 48 \mathrm{~h}$ following transfection (Figure $3 \mathrm{C} ; P<0.001$ ). In concert with these results, exposure of DLD-1 cells to IL-4 primarily increased NOX1-L expression (Supplementary Figure S1G), which was associated with increased tumor cell proliferation and ROS production (Supplementary Figures S1E and S1F).

However, when WiDr cells were treated with IL-4 for $24 \mathrm{~h}, N O X 1-L$ did not appear to be specifically induced, which led to no discernable effect of IL-4 on reactive oxygen production or cell cycle progression (Figures 3D, 3E, and 3F). On the other hand, if WiDr cells were transiently transfected with $N O X 1-L$, production of ROS $48 \mathrm{~h}$ after transfection was significantly increased $(P<0.001)$, as was the S-phase fraction (Figures $3 \mathrm{E}$ and $3 F$ ). Finally, we found that in HT-29 cells (but not WiDr cells), upregulation of functional NOX1 was associated with a modest increase in the expression of cyclin $\mathrm{D}_{3}$, which could help to explain the enhanced cell cycle traverse through $\mathrm{G}_{1}$ that we observed (Figure $3 \mathrm{G}$ ). Taken together, these results suggest that enhanced expression of NOX1-L promotes ROS generation that is associated with an increase in cell cycle progression in human colon cancer cells.

\section{Induction of NOX1 expression by IL-4 or IL-13 requires the presence of functional IL-4Ra}

To examine the requirement for functional IL-4 or IL-13 binding to the Type II IL-4R in the induction of NOX1 expression, IL-4R $\alpha$ expression was knocked down with two different small interfering RNAs [siRNAs] (Figure 4A and Supplementary Figure S3A). We found that inhibition of IL-4R $\alpha$ expression significantly decreased IL-4- or IL-13-stimulated NOX1 expression in HT-29 cells at both the mRNA $(P<0.001)$ and protein levels (Figures 4A and 4B; Supplementary Figure S3A). When HT-29 cells were pretreated with a neutralizing mouse anti-human monoclonal antibody against the IL-4R $\alpha$ chain (R \& D Systems; Clone 25463), prior to treatment with IL-4 or IL-13, cytokine-enhanced NOX1 expression was significantly decreased (Figures 4C and Supplementary Figure S3B; $P<0.001)$. As shown in Figure 4D, the simultaneous presence of the neutralizing antibody and IL-4 blocked IL-4-enhanced proliferation of HT-29 cells $(P<0.01)$. These results indicate that the Type II IL-4R is required for IL-4 or IL-13-mediated NOX1 upregulation and also suggest that IL-4 and IL-13 could share the same signaling pathway to induce NOX1 expression.

\section{JAK1/STAT6 signaling pathway is involved in the induction of NOX1 by IL-4 and IL-13}

Three members of the Janus Kinase family, JAK1, JAK2, and JAK3, have been reported to associate with components of the IL-4R complex [27]. We found that JAK1 was the major Janus Kinase family member expressed in HT-29 cells (Supplementary Figure S4A). When JAK1 was silenced with two independent siRNAs, IL-4-induced NOX1 expression was decreased at both mRNA $(P<0.001$; Figure 5A) and protein levels (Figure $5 B)$. Knockdown of JAK2 had no effect on NOX1 expression that was increased by IL-4 (Supplementary 


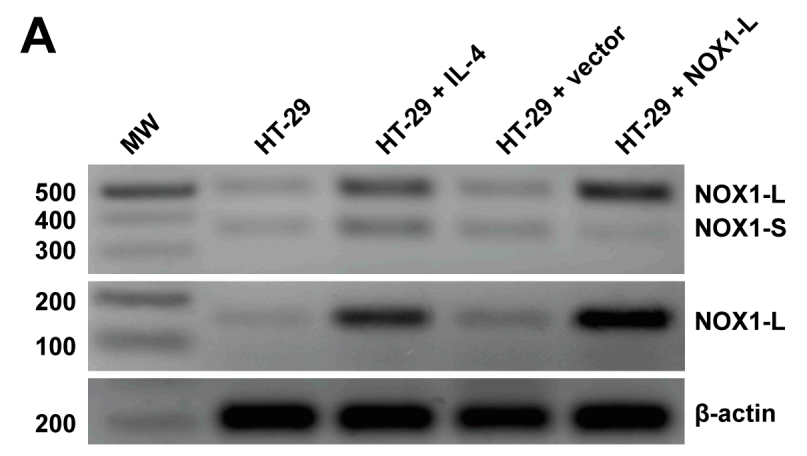

C

\begin{tabular}{lllr} 
& \multicolumn{1}{c}{ \%G0/G1 } & \%S (BrdU+) & \multicolumn{1}{c}{ \%G2 } \\
\hline HT-29 (N=4) & $53.9( \pm 1.3)$ & $38.5( \pm 1.2)$ & $9.87( \pm 0.7)$ \\
HT-29 + IL-4 $(\mathrm{N}=4)$ & $45.2( \pm 1.4)^{\star \star \star}$ & $44.2( \pm 1.3)^{\star \star \star}$ & $9.72( \pm 1.1)$ \\
HT-29 + vector $(\mathrm{N}=4)$ & $52.5( \pm 1.2)$ & $31.2( \pm 1.1)$ & $15.10( \pm 0.8)$ \\
HT-29 + NOX1-L $(\mathrm{N}=4)$ & $45.6( \pm 1.2)^{\star \star}$ & $38.5( \pm 0.9)^{\star \star \star}$ & $15.00( \pm 1.1)$
\end{tabular}

B

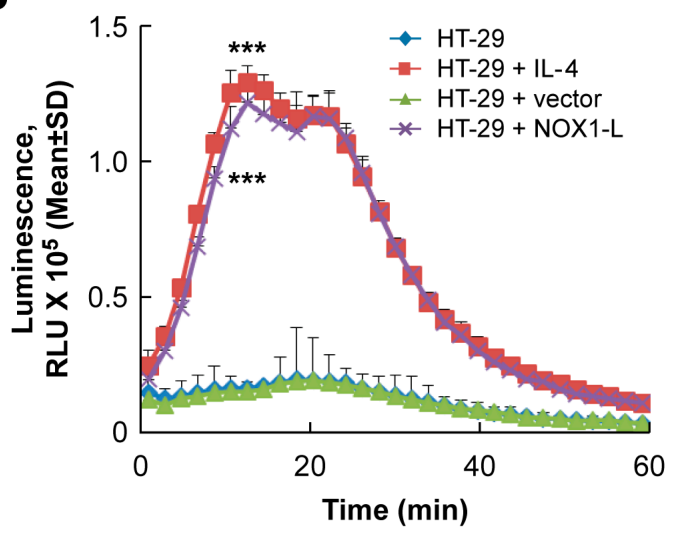

D

E

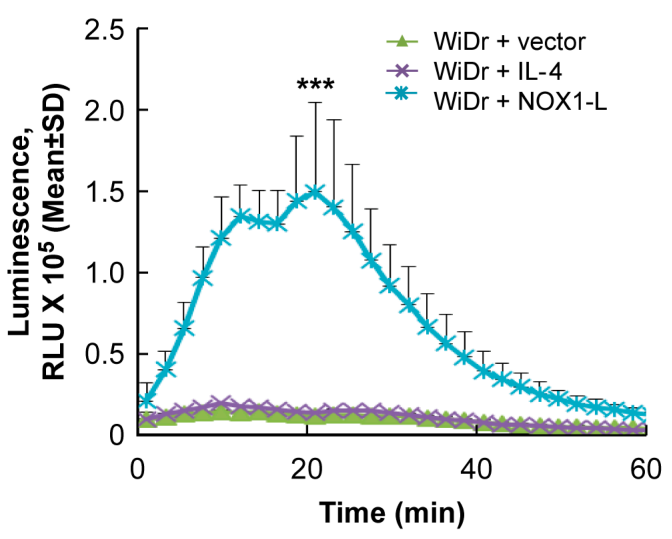

G

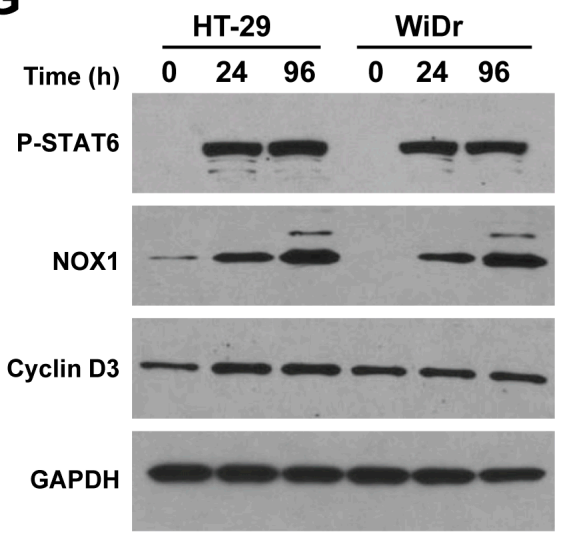


Figure 3: Functional activity of NOX1 correlates with colon cancer cell proliferation. A. IL-4 exposure for $24 \mathrm{~h}$ increases expression of full-length NOX1 in HT-29 cells. PCR and subsequent DNA gel analysis were performed to detect NOX1-L and NOX1-S in IL-4-treated HT-29 cells. A NOX1- $L$ construct was transiently transfected into HT-29 cells and used as the control $48 \mathrm{~h}$ after transfection. B. IL-4 treatment $(50 \mathrm{ng} / \mathrm{ml}$ for $24 \mathrm{~h})$ supports PMA-stimulated superoxide production in HT-29 cells. HT-29 cells $48 \mathrm{~h}$ after transient transfection with a NOX1-L construct served as a positive control. C. Cell cycle analysis was performed using analytical cytometry following BrdU labeling of HT-29 cells that had been treated for $24 \mathrm{~h}$ with $50 \mathrm{ng} / \mathrm{ml}$ of IL-4. HT-29 cells evaluated $48 \mathrm{~h}$ after transient transfection with NOX1-L were used as the control. The percentage of cells in the different phases of the cell cycle is shown in the table. D. IL-4 exposure $(50 \mathrm{ng} / \mathrm{ml}$ for $24 \mathrm{~h})$ increases the expression of $N O X 1$ in WiDr cells. PCR and subsequent DNA gel analysis were performed to detect NOX1-L and NOX1-S in WiDr cells treated with IL-4. Transient transfection of NOX1-L into WiDr cells served as the control. E. NOX1-L rather than NOX1-S supports PMA-stimulated superoxide production in WiDr cells. WiDr cells treated with IL-4 (50 ng/ml for $24 \mathrm{~h}$ ) or $48 \mathrm{~h}$ after transient transfection with a NOX1-L construct were evaluated for the extent of PMA-induced superoxide production. F. Cell cycle analysis was performed using analytical cytometry following BrdU labeling of WiDr cells that had been treated for $24 \mathrm{~h}$ with $50 \mathrm{ng} / \mathrm{ml}$ of IL-4. WiDr cells evaluated $48 \mathrm{~h}$ after transient transfection with NOX1-L were used as the control. The percentage of cells in the different phases of the cell cycle is shown in the table. G. Western analysis was performed on HT-29 and WiDr cells treated with IL-4 $(50 \mathrm{ng} / \mathrm{ml})$ for variable periods of time $(0,24,96 \mathrm{~h})$. Activated STAT6 and NOX1 levels were examined as indicators of IL-4 efficacy in these experiments; GAPDH served as the loading control. All data represent the mean $\pm \mathrm{SD}$ of at least three experiments. $* * *=P<0.001$.

Figure S4B). Unfortunately, lack of a phospho-specific JAK-1 antibody impeded determination of the critical tyrosine residues required for JAK-1 activation. We next examined whether members of the STAT family were activated by IL-4, since STAT6 has been reported previously to play an important role in signal transduction associated with IL-4 exposure [40]. Treatment of HT-29 cells with IL-4 was followed by a rapid increase in the phosphorylation of STAT1, 5, and 6 (but not STAT3) (Figure 5C); however, only phosphorylated STAT6 (p-STAT6), which is phosphorylated by the receptor associated kinase JAK1, remained highly activated for the full $96 \mathrm{~h}$ of cytokine exposure. STAT6 phosphorylation was blocked by JAK1 specific siRNAs (Figure 5B), suggesting that STAT6 is downstream of JAK1 and may be involved in the IL-4-related increase in NOX1 expression. STAT6 knockdown experiments confirmed the involvement of this transcription factor in IL-4induced NOX1 expression (Figures 5D and E). In related experiments, we found that both JAK1 and STAT6 played an important role in modulating IL-13-related NOX1 expression (Supplementary Figures S4C and S4D). These results strongly suggest that JAK1 and STAT6 can mediate enhanced expression of NOX1 produced by IL-4 and IL-13, consistent with previous data suggesting that STAT6 is a principal STAT activated in response to IL-4 stimulation, where it plays a critical role in modifying the expression of IL-4-responsive genes [48]. We hypothesize that the prolonged activation of STAT6, furthermore, might have been enhanced by ROS-related inhibition of redox sensitive PTP moieties (observed for the HT-29 line but not for WiDr cells that lack functional NOX1) (Figure 5F). It is important to point out in this regard that beyond activating the JAK/STAT pathway, IL-4 and IL13 can increase MAPK (ERK1/2) signaling in a fashion that depends on NOX1-related ROS formation and is associated with altered phosphatase function [26].

\section{IL-4-enhanced NOX1 expression depends on the activation of GATA3 by S308 phosphorylation}

Although IL-4 enhanced the phosphorylation of STAT6, and STAT6 knockdown blocked the induction of NOX1 expression in HT-29 cells, we could not define consensus STAT6 binding sequences in the NOX1 promoter. This observation suggested that other transcription factors might be involved that could link STAT6 activation with the induction of NOX1 expression. Previous studies of $\mathrm{CD}^{+} \mathrm{T}$ cell differentiation indicated that GATA3 was selectively induced by IL-4 following STAT6 activation [49]. Upon further investigation, we found that the NOX1 promoter contained four possible GATA3 binding sites. As demonstrated in Figure 6A, IL-4 treatment increased the nuclear expression of GATA3; the time course of STAT6 phosphorylation and increased GATA3 expression in the nucleus suggested that activation of STAT6 preceded that of GATA3 (Supplementary Figure S5A). Silencing GATA3 with two independent siRNAs blocked IL-4- or IL-13-enhanced NOX1 mRNA expression (Figure 6B, $P<0.001$; Supplementary Figure S6A, $P<0.001)$ as well as baseline and IL-4-enhanced protein expression (Figure $6 \mathrm{C}$ ). These results suggest that GATA3 is an activator of NOX1 expression following IL-4 or IL-13 stimulation.

Because phosphorylation of GATA3 appears to be required for its translocation to the nucleus and subsequent effects on gene transcription [50,51], we examined whether GATA3 phosphorylation was necessary for IL-4-induced NOX1 expression. Immunoprecipitation experiments revealed that IL-4 treatment increased the phosphorylation of serine residues on GATA3 in HT-29 cells compared to vehicle-treated controls (Figure 6D). Transient overexpression of GATA3 increased IL-4induced NOX1 expression in HT-29 cells (Figure 6E). However, HT-29 cells transiently transfected with a GATA3 construct carrying a mutation at S308A failed to induce NOX1 expression following IL-4 treatment 
A
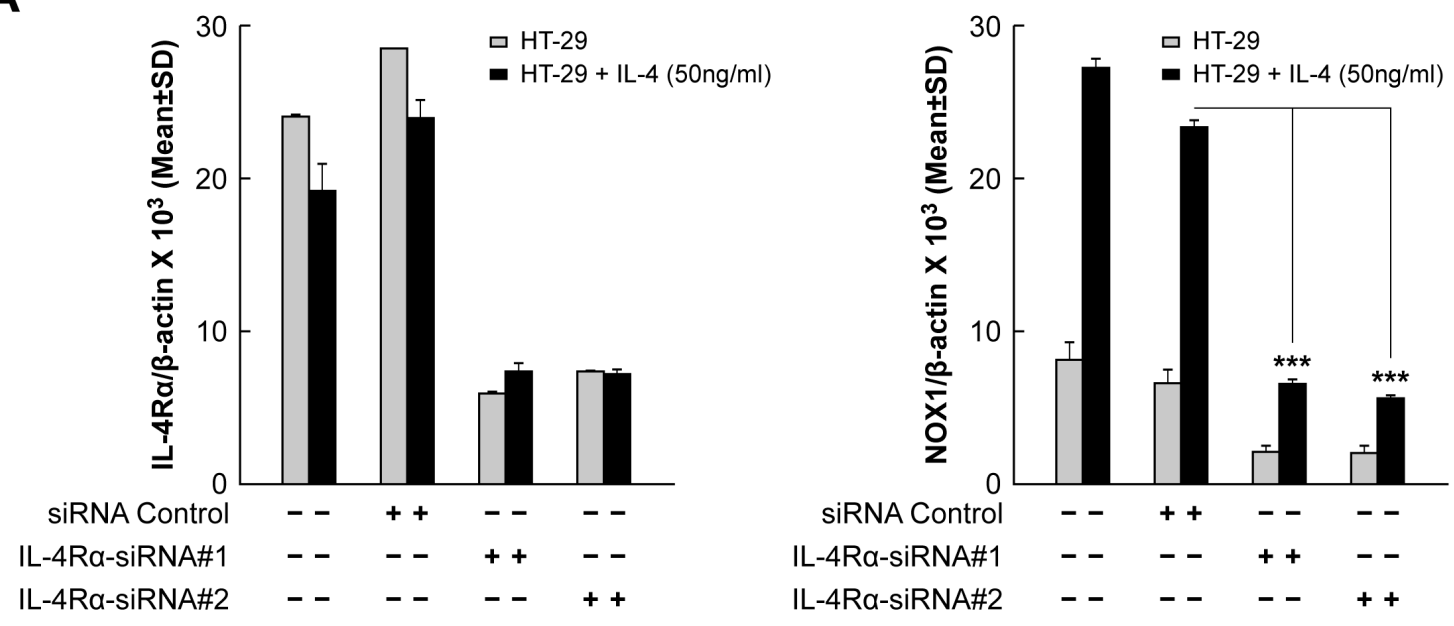

B

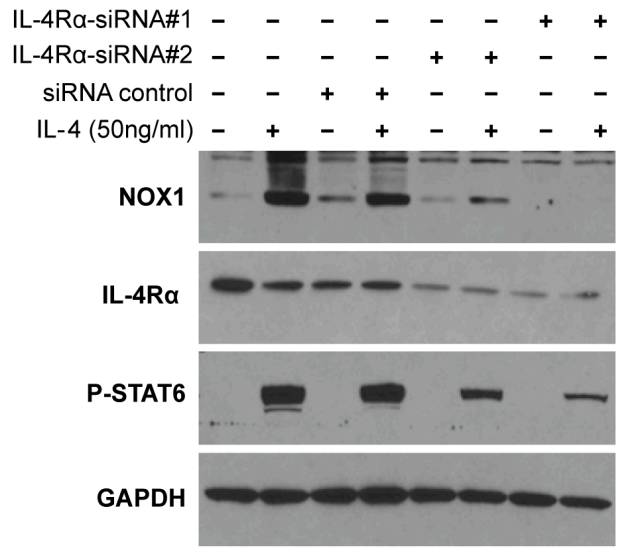

C

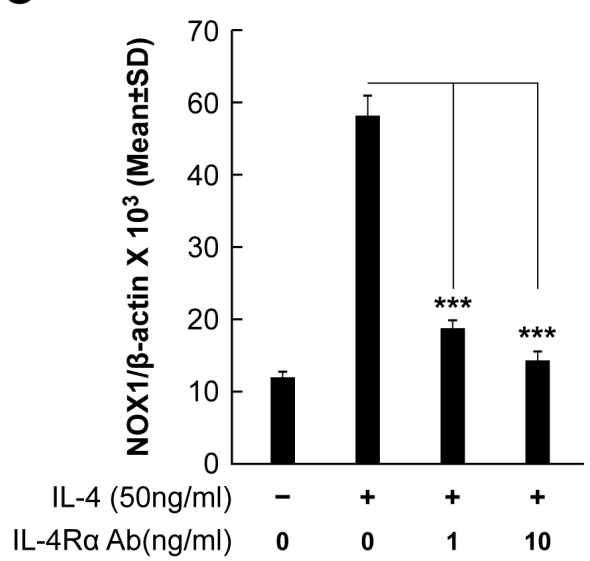

D

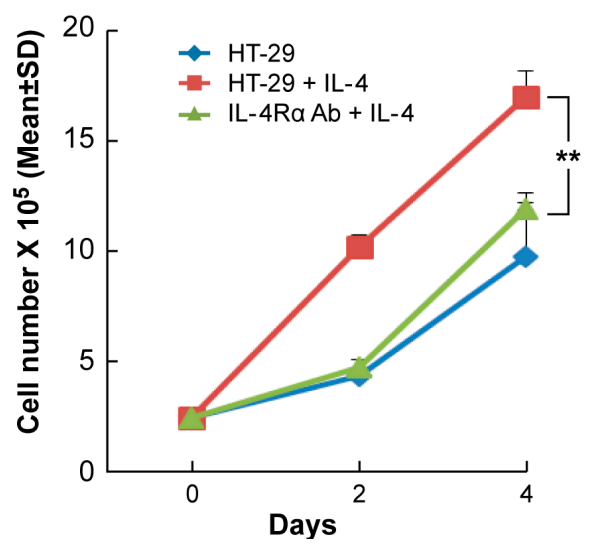

Figure 4: Inhibition of IL-4R blocks IL-4-induced NOX1 expression. A.-B. Knockdown of IL-4R $\alpha$ blocks NOX1 expression at the mRNA A. and protein B. levels. HT-29 cells were transiently transfected with either of the two different IL-4R $\alpha$ specific siRNAs and treated with IL-4 $(50 \mathrm{ng} / \mathrm{ml}) 24 \mathrm{~h}$ later. Cells were harvested $24 \mathrm{~h}$ post-treatment and examined by quantitative RT-PCR A. or by Western analysis B.. $\beta$-actin and GAPDH served as the internal controls for RT-PCR or Western analysis, respectively. C. IL-4-induced NOX1 expression requires the presence of IL-4R. IL-4-induced NOX1 expression was abolished in HT-29 by the concurrent presence of an IL-4R $\alpha$ neutralizing antibody in the absence of FBS, as shown by quantitative RT-PCR. D. IL-4 stimulates cell proliferation through the involvement of IL-4R. IL-4R $\alpha$ antibody $(1 \mathrm{ng} / \mathrm{ml})$ significantly inhibited IL-4-enhanced HT-29 proliferation. Data represent the mean $\pm \mathrm{SD}$ of three experiments. $* *=P<0.01 ; * * *=P<0.001$. 
(Figure 6E). These results support a role for serine phosphorylation of GATA3 in the mechanism of IL-4induced NOX1 expression.

\section{Transcriptional regulation by GATA3 plays a major role in the induction of NOX1 expression by IL-4 and IL-13}

Using promoter-reporter assays, we sought to define whether GATA3 binding to the NOX1 promoter played a critical role in IL-4-dependent upregulation of
NOX1 expression. In the presence of IL-4, reporter gene transcription, from a 960-bp segment corresponding to -179 to -1139 bps of the promoter sequence upstream from the NOX1 transcription start site (Figure 7A), increased luciferase activity $\approx 4$-fold in HT-29 cells (Figure 7B). Further analysis of this sequence predicted four putative GATA binding sites: -966/-960, -321/-315, $-226 /-220$, and $-203 /-197$. To test the potency of these predicted binding sites to induce NOX1 transcription following IL-4 exposure, we developed individual mutants of each potential GATA binding site (Figure 7A). When the GATA3 cis-element, -321/-315, was mutated
A

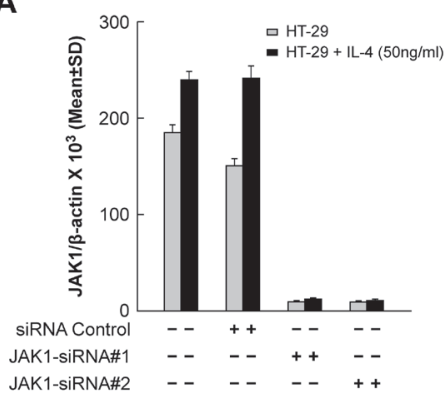

C

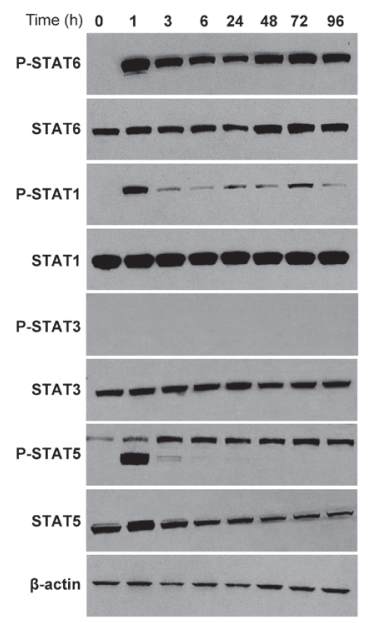

D
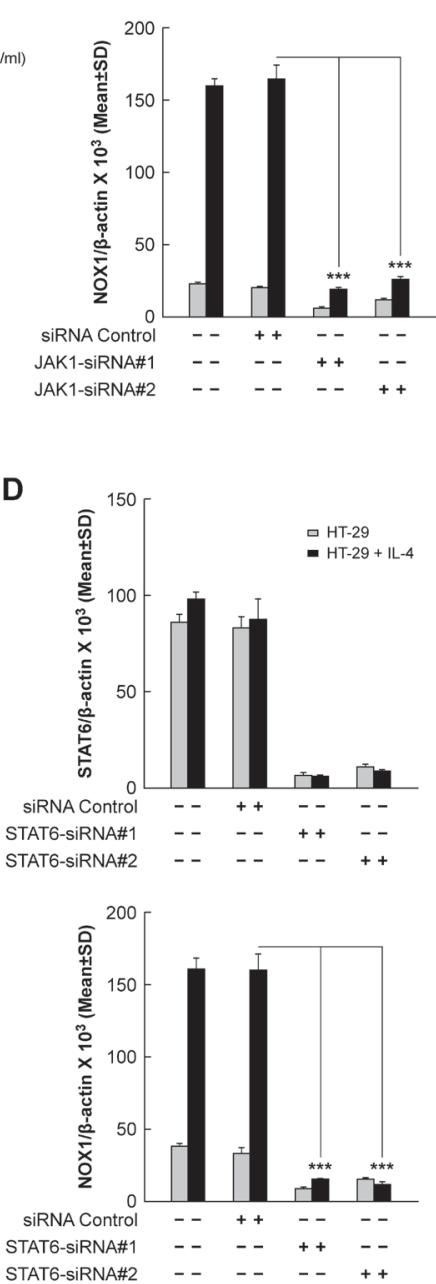

B

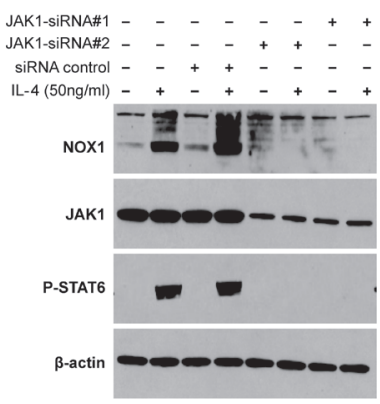

E

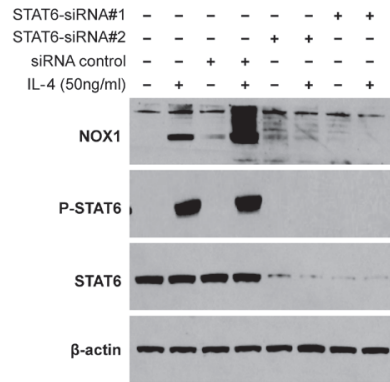

$\mathbf{F}$

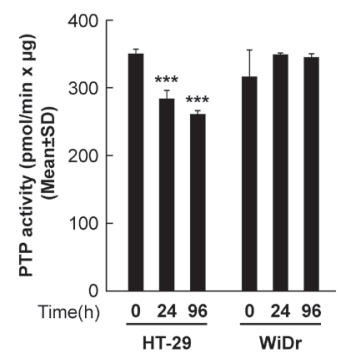

Figure 5: JAK1/STAT6 activation is required for IL-4-induced NOX1 expression. A.-B. JAK1 knockdown blocks IL-4mediated enhancement of NOX1 expression at the mRNA A. and protein levels B.. HT-29 cells were transiently transfected with either of the two different JAK1-specific siRNAs and treated with IL-4 $(50 \mathrm{ng} / \mathrm{ml}) 24 \mathrm{~h}$ later. Cells were harvested at $24 \mathrm{~h}$ post-treatment and examined by quantitative RT-PCR A. and Western analysis B.. $\beta$-actin served as the internal control. C. IL-4 treatment results in a transient increase in phosphorylated STAT1 and STAT5, and a sustained increase in phosphorylated STAT6. Western analysis was performed on IL-4 $(50 \mathrm{ng} / \mathrm{ml})$-treated HT-29 cells harvested at different time points following initiation of IL-4 exposure. $\beta$-actin served as the loading control. (D.-E.) STAT6 knockdown blocks IL-4-related stimulation of NOX1 expression at the mRNA D. and protein levels E.. HT-29 cells were transiently transfected with either of two different STAT6-specific siRNAs and treated with IL-4 $24 \mathrm{~h}$ later. Cells were harvested at 24 h post-treatment and examined by quantitative RT-PCR D. and Western analysis E.. F. PTP activity was evaluated in HT-29 and WiDr cells following exposure to IL-4 $(50 \mathrm{ng} / \mathrm{ml})$ for the indicated times. PTP levels were determined by measuring the dephosphorylation of a standard phosphopeptide using malachite green as the detector. $\beta$-actin served as the internal control. Data represent the mean $\pm \mathrm{SD}$ of three experiments. $* * *=P<0.001$. 
(mutation \#2), NOX1 promoter-reporter gene transcription was completely abolished (Figure 7B), supporting the involvement of GATA3 in IL-4-enhanced NOX1 expression, as well as the involvement of the $-321 /-315$ GATA3 cis-element. In contrast, mutations in the other three GATA family cis- elements did not influence NOX1 promoter-reporter gene transcription in the presence of
IL-4. These results suggest that the conserved consensus sequence required for the binding of GATA3 is $-321 /-315$. We also performed chromatin immunoprecipitation (ChIP) assays to detect GATA3 binding to the NOX1 promoter. The primers utilized were specific for the possible GATA3 binding site defined by the mutation studies: bp -321/315. Our results demonstrated that GATA3 binding was
A

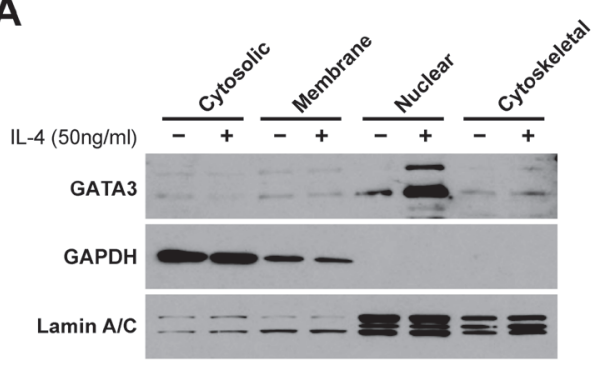

\section{C}

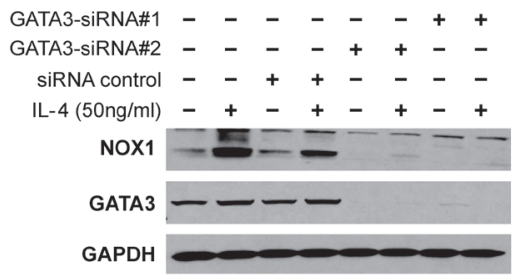

$\mathbf{E}$

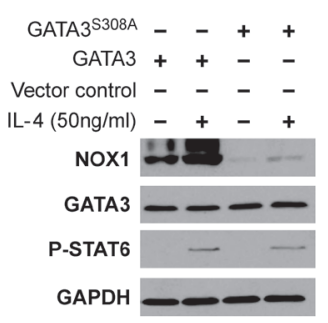

B
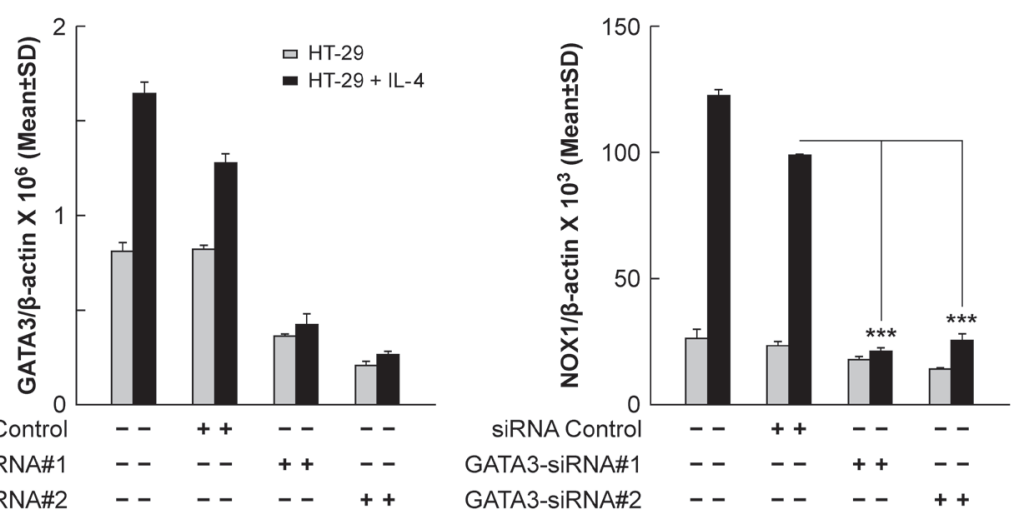

D

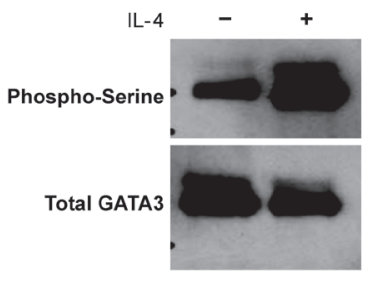

$\mathbf{F}$

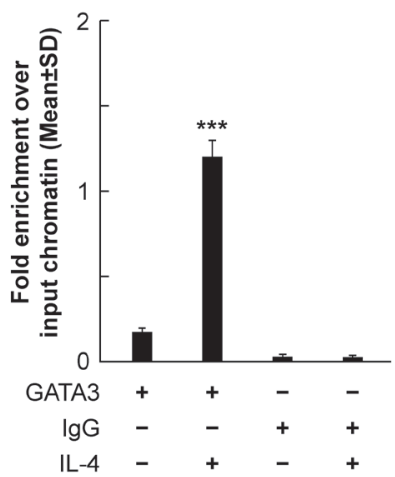

Figure 6: GATA3 plays a role in the transcriptional regulation of NOX1. A. IL-4 triggers GATA3 nuclear translocation demonstrated by Western analysis of HT-29 cells treated for $24 \mathrm{~h}$ with IL-4. GAPDH and Lamin A/C were used as the cytosolic and the nuclear protein loading controls, respectively. B.-C. GATA3 knockdown blocks increased NOX1 mRNA expression following IL-4 stimulation $(50 \mathrm{ng} / \mathrm{ml})$ at the mRNA B. and protein levels C.. HT-29 cells were transiently transfected with either of two different GATA3-specific siRNAs and treated with IL-4 $24 \mathrm{~h}$ later. Cells were harvested $24 \mathrm{~h}$ following IL-4 treatment and examined by quantitative RT-PCR B. and Western analysis C. $\beta$-actin and GAPDH served as the internal controls. D. The serine residues of GATA3 are phosphorylated following IL-4 stimulation. Immunoprecipitation of GATA3 and subsequent Western analysis to determine the extent of serine phosphorylation were performed on HT-29 cells treated with solvent or IL-4 $(50 \mathrm{ng} / \mathrm{ml}$ for $24 \mathrm{~h})$. E. Serine-phosphorylation of GATA3 is a prerequisite for IL-4induced NOX1 expression. Western analysis was performed on HT-29 cells expressing either intact GATA3 or GATA3 ${ }^{\text {S308A }}$. F. Fragments corresponding to the $N O X 1$ promoter region, pulled down with a GATA3 antibody, are enriched following treatment with $50 \mathrm{ng} / \mathrm{ml}$ of IL-4 for $24 \mathrm{~h}$. Chromatin immunoprecipitation assay and subsequent quantitative PCR were performed on HT-29 cells exposed to IL-4 (50 ng/ $\mathrm{ml}$ ) or solvent. Isotype-matched $\mathrm{IgG}$ was used as the control. Data represent the mean $\pm \mathrm{SD}$ of three experiments. $* * *=P<0.001$. 
significantly increased following treatment with either IL-4 or IL-13 (Figure 6F; Supplementary Figure S6B). Furthermore, STAT6 knockdown inhibited the binding of GATA3 to the NOX1 promoter site, suggesting that GATA3 responds to STAT6 activation upon IL-4 exposure
(Supplementary Figure S5B). Taken together, these data provide evidence demonstrating that IL-4 and IL-13 upregulate NOX1 in colon cancer cells though the IL-4R/ STAT6 pathway, and that GATA3 plays an important role in the transcriptional regulation of NOX1.

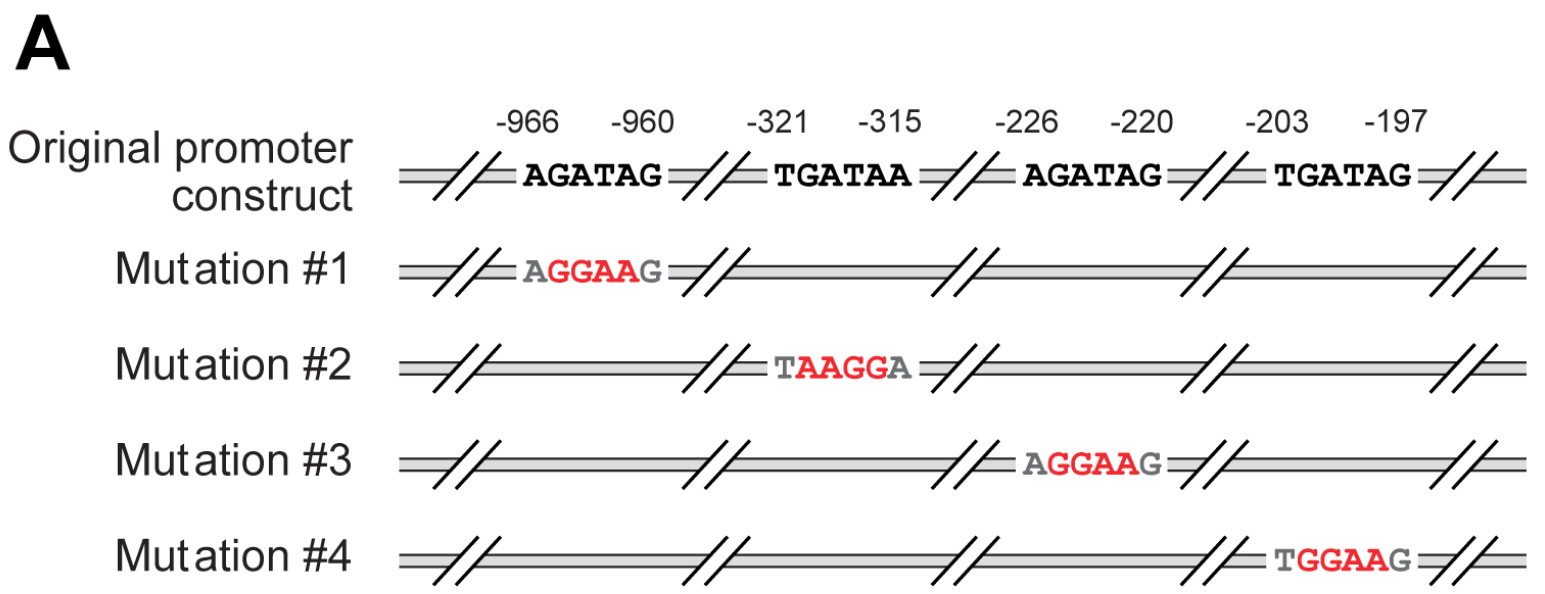

B

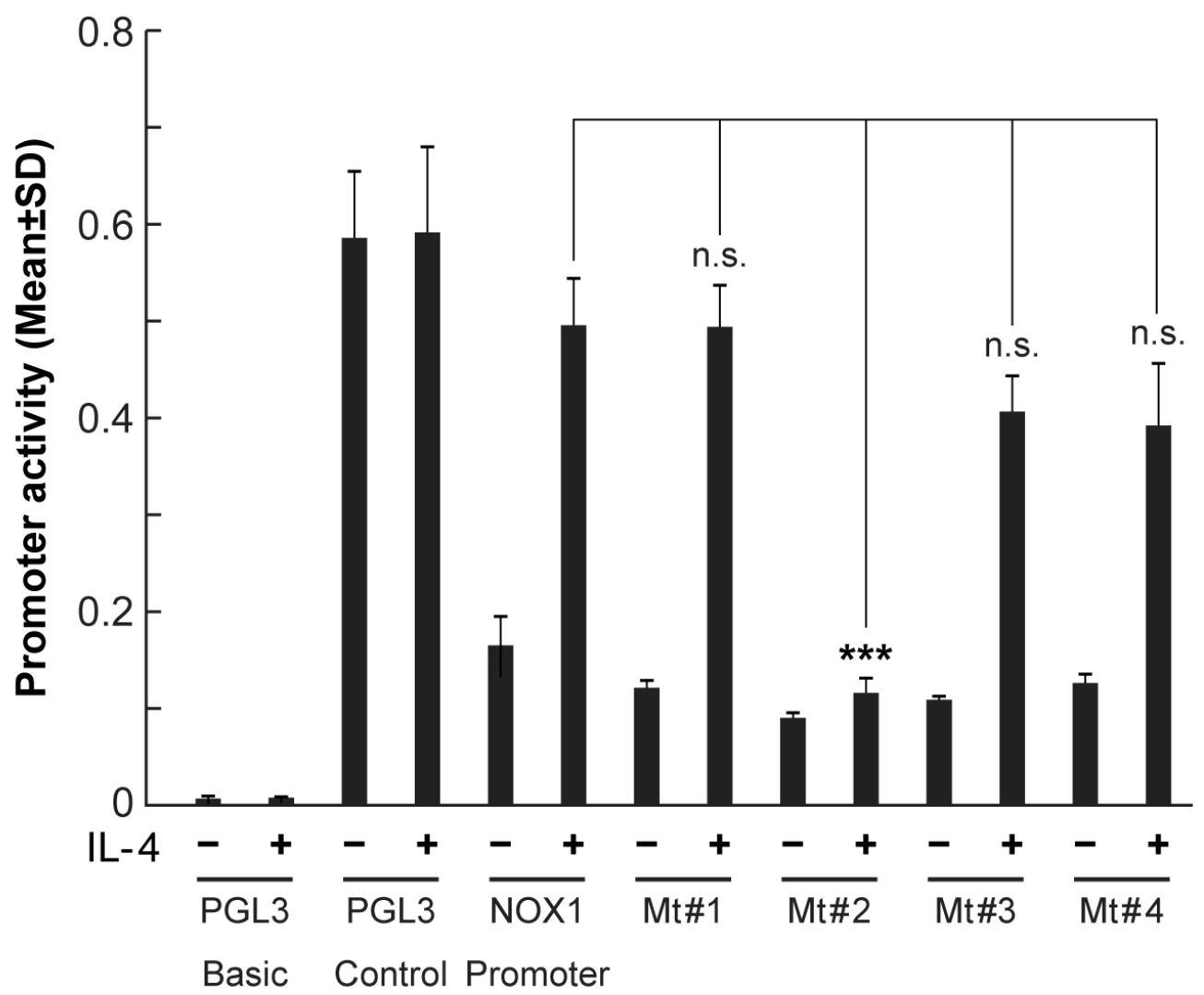

Figure 7: GATA3 binds to NOX1 promoter region -321/-315. A. Schematic illustration of the NOX1 promoter region and its variants generated by mutagenesis, highlighting the potential GATA3 binding sites. Mutated binding sites are shown in red. These promoter regions were individually constructed as PGL3 reporters. B. Mutation at the $-321 /-315$ region abolishes luciferase activity associated with IL-4-mediated NOX1 promoter activity. HT-29 cells were transfected with the individual reporter constructs in the presence or absence of IL-4 $(50 \mathrm{ng} / \mathrm{ml})$, and luciferase activity was measured $48 \mathrm{~h}$ later. Data represent the mean $\pm \mathrm{SD}$ of three experiments. $* * *=P<0.001 ; \mathrm{n} . \mathrm{s}$. $=$ not significant. 


\section{NOX1 expression in human colon cancers and its relationship to IL-4R expression in colon cancer and adjacent colonic epithelium}

To examine the clinical relevance of our finding that in colon cancer cell lines IL-4 upregulates the expression of a functional NOX1-L isoform, we measured NOX1 expression in twenty tissue pairs consisting of surgicallyresected colon cancers and their adjacent normal colonic mucosae. We found that mRNA levels of total NOX1, as well as the NOX1-L isoform, were significantly higher in tumors compared to uninvolved, adjacent colonic epithelium (Figure 8A). Furthermore, there was a significant relationship in both tumor samples and normal tissues between levels of IL-4R $\alpha$ and NOX1 mRNA (Figure 8B). The relationship between IL-4R $\alpha$ and NOX1 in these tumors and adjacent normal tissues suggests that the conditions exist in the clinic to support a mechanistic relationship between IL-4 and colon cancer proliferation.

\section{DISCUSSION}

A growing body of evidence supports a role for the $\mathrm{T}_{\mathrm{H}}$ 2-cytokines IL-4 and IL-13 in the pathogenesis of pre-malignant chronic inflammatory diseases of the gastrointestinal tract [52-55] and in the enhancement of colorectal cancer cell proliferation [31, 39, 56]. Furthermore, recent studies have demonstrated that IL-4 and IL-13, as well as the Type II receptor they share, are expressed widely in human colorectal cancers $[31,57]$, as well as in a variety of other epithelial malignancies $[35,37]$. Enhanced cellular proliferation in the presence of IL-4 or IL-13 has, for the most part, been attributed to increased JAK/STAT signaling (primarily through STAT6) [48] or to the upregulation of the expression of survivin and other anti-apoptotic proteins, including Bcl-2 and Bcl$\mathrm{xL}[39,46]$.

For the experiments reported herein, we explored another potential mechanism of IL-4- or IL-13-mediated growth control: the generation of ROS. We found that both cytokines increased the expression of NOX1 (but not other NOX species) over a period of 12 to $48 \mathrm{~h}$ in a panel of human colorectal cancer cell lines that possess the Type II IL-4R. The extent of functional NOX1 expression in HT-29 and DLD-1 human colon cancer cells, as measured by the generation of ROS (Figures 2B and 2C; Supplementary Figure S1B and S1F) correlated well with the degree of tumor cell growth stimulation by IL-4 or IL13; in the presence of near-complete NOX1 knockdown (which had no effect on the expression of the Type II IL4R), IL-4 exposure did not affect the growth rate of the tumor cells (Figure 2D). Enhanced cellular proliferation was dependent upon the presence of a functional Type II IL-4R (Figure 4D) and involved an acceleration of cell cycle progression through S-phase (Figure 3C).
These results mirror our recent demonstration of the effects of stable NOX1 knockdown with shRNA in HT-29 cells [16]; in those experiments, we found that inhibition of NOX1 expression (and consequently of ROS formation) in the HT-29 line produced a profound block in cell cycle progression at the $\mathrm{G}_{1}$ interface (related to diminished cyclin $\mathrm{D}_{1}$ expression), leading to a significant decrease in tumor cell proliferation. We have also shown that inhibition of NOX1 activity with diphenylene Iodonium [DPI] or 2-di-thienyl Iodonium [DTI] also induced a $\mathrm{G}_{1}$ block in HT-29 cells with an associated decrease in tumor cell growth [17]. In related studies by other laboratories, marked $\mathrm{G}_{1}$ delay has been demonstrated following exposure of fibroblasts to the ROS scavenger $\mathrm{N}$-acetyl-L-cysteine [58] or following overexpression of catalase (which detoxifies $\mathrm{H}_{2} \mathrm{O}_{2}$ ) in murine aortic endothelial cells [59]. Thus, demonstration of enhanced BrdU incorporation in HT-29 and WiDr colon cancer cells following IL-4 exposure or transient transfection of NOX1-L, respectively, is consistent with ROS-related regulation of cyclin $\mathrm{D}_{3}$ levels in our colon cancer lines, and is in harmony with a previous study of the effect of NOX1 levels on cyclin $\mathrm{D}_{1}$ expression in murine lung epithelial cells [60].

However, our results differ, at least in part, from a previous report that examined the effect of IL-4 [41] on reactive oxygen production by human tumor cells. In this study, cytokine exposure was reported to induce immediate (1-15 min), ligand-dependent ROS production that required the presence of NOX1 (and potentially other NADPH oxidases including NOX4, NOX5, and DUOX2). Because of these differences, we performed control experiments to examine the time course of ROS production following IL-4 exposure in human colorectal cancer cells. As shown in Figure 2C, we found no evidence of an immediate burst of ROS production, as measured by DCF fluorescence, following cytokine exposure in HT-29 cells. These results are consistent with a previous study from our laboratory which demonstrated by real time RTPCR that the constitutive expression levels of all seven NOX homologues in the A549 human lung cancer line were at or below the lower limit of detection for our PCR assay [61].

It should also be pointed out that some previous studies have reported that IL-4 is growth inhibitory for certain colorectal cancer cells, including the HT-29 cell line $[62,63]$, while stimulating tumor cell proliferation in other tumor cell types [63]. Specific activation of STAT1 with the induction of p21-dependent growth arrest was proposed as the mechanism of growth inhibition in the study by Chang and colleagues [63]. However, as demonstrated in Figure 5C, we found that exposing HT-29 cells to IL-4 produced a profound and prolonged $(96 \mathrm{~h})$ activation of STAT6, but only transient (1-3 h) phosphorylation of STAT1, that was associated with IL-4dependent, enhanced cell cycle progression. Furthermore, 

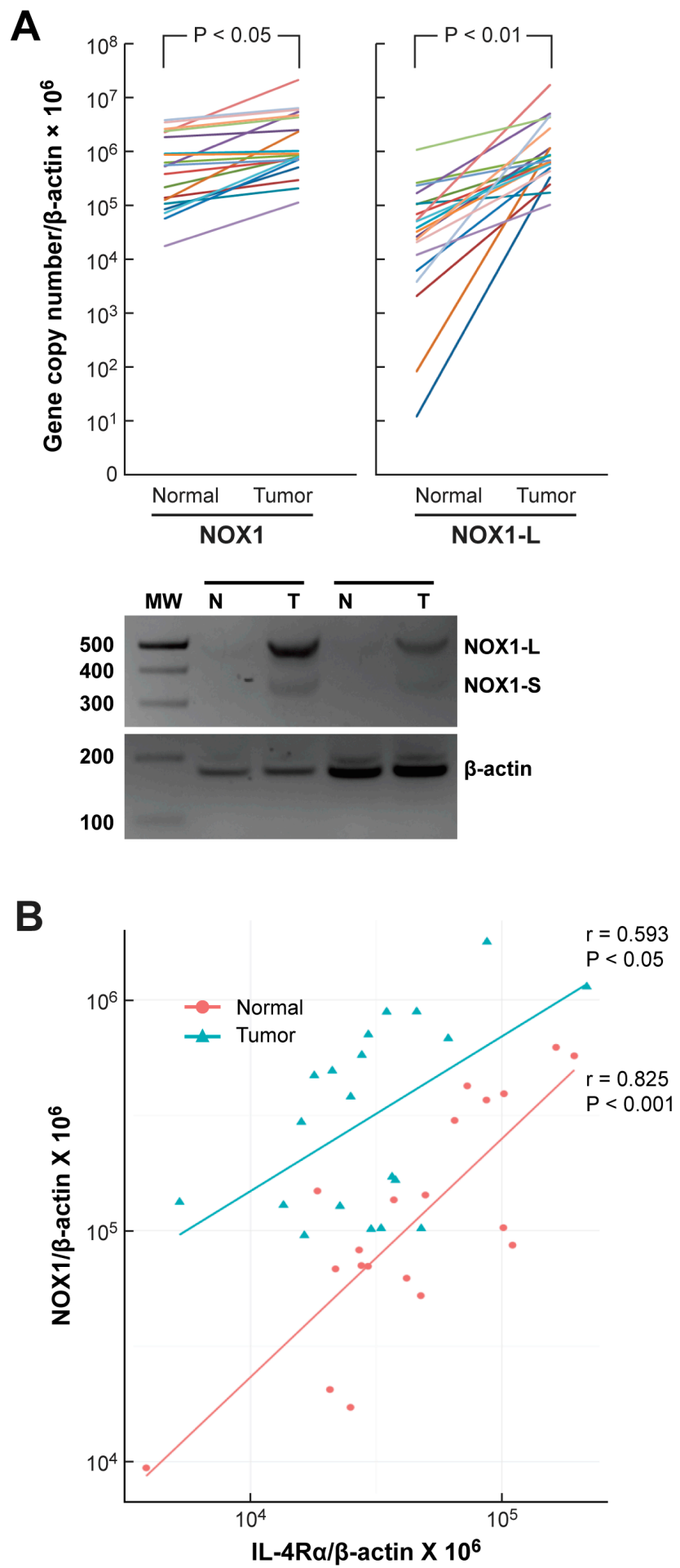

Figure 8: NOX1 expression in human colon cancers and adjacent uninvolved colonic epithelium and its relationship to IL-4R $\alpha$ expression. A. Twenty pairs of human colon cancer surgical specimens and adjacent normal colonic epithelium were analyzed by quantitative RT-PCR for the expression of NOX1 and its functional isoform NOX1-L. $\beta$-actin served as the control. Paired, two-tailed $t$ tests were used to evaluate the results; the Wilcoxon signed rank test was also used to test for differences in expression level between tumor and normal samples. The likelihood of our observations occurring if there was truly no difference in the expression between tumor and normal samples is $<0.0001$. The lower panel shows the results of two representative patient samples in which cDNA was cloned from the surgical samples and subjected to PCR to examine the abundance of different NOX1 isoforms (NOX1-L and NOX1-S). B. NOX1 and IL-4 $\alpha$ expression levels were examined by quantitative RT-PCR using the tumors (blue) and the respective adjacent normal tissues (red) of 20 colon cancer patients. $\beta$-actin served as the internal control. Pearson's correlation coefficient $(\mathrm{r})$ and level of significance $(P)$ using a two-tailed $t$ test for both groups are shown in the figure. 
when IL-4 was administered to patients with a variety of solid tumors in prior clinical trials, no meaningful therapeutic activity was demonstrated [64]. These results, in concert with evidence that IL-4 stimulates the growth of primary colon cancer cell and normal enterocyte growth (in addition to human colorectal cancer cell lines), suggest that the preponderance of evidence favors an important role for the proliferative potential of IL-4 [38] in human cancers [39].

In addition to increasing NOX1-dependent cell cycle progression, as reported in this study, IL-4 has been demonstrated to stimulate tumor cell proliferation by enhancing the expression of anti-apoptotic proteins and/or signaling through the MAPK pathway [40]. We found in previous experiments [26] that IL-4-related MAPK signaling may be mediated by NOX1-dependent ROS production. Based on those results, it could be hypothesized that the enhanced proliferation we observed in parental and scrambled shRNA-containing
HT-29 cells following IL-4 exposure (but not in NOX1 knockdown cells) may be a downstream consequence of ROS-related ERK activation on the cell cycle regulatory apparatus [65]. Although upregulation of anti-apoptotic proteins undoubtedly contributes to IL-4-induced growth enhancement in several model systems [39], such an effect of IL-4 does not appear to fully explain our results with HT-29 cells (Supplementary Figure S2D).

The regulation of NOX1 activity has traditionally been attributed to variations in the association or phosphorylation of members of the NOX1 complex (NOXO1, NOXA1, p22 phox, and Rac) [11]. However, studies of NOX1 expression in Caco-2 human colorectal cancer cells demonstrated that binding of the transcription factor GATA6 to the NOX1 promoter played an important role in the regulation of NOX1 expression [66, 67]. In contrast, initiation of $I L-4$ transcription in naïve T cells is regulated by GATA3 [29]; and the expression of GATA3 is significantly increased in the bowel mucosae of children

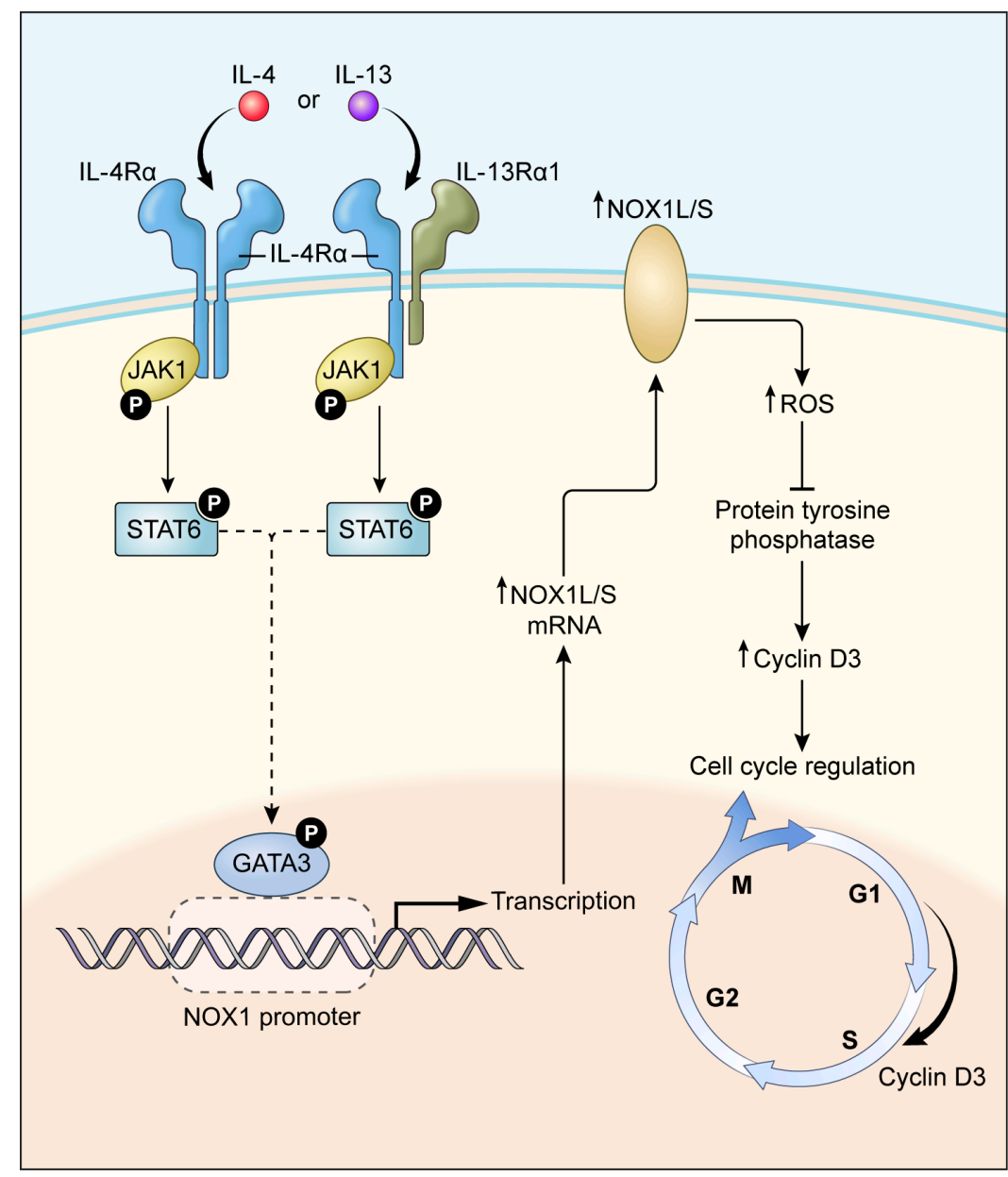

Figure 9: A proposed model for IL-4/IL-13-induced NOX1 expression and colon cell proliferation. IL-4/IL-13 bind to the Type II IL-4 receptor activating the JAK1/STAT6 signaling pathway, triggering GATA3 nuclear translocation that drives NOX1 expression. GATA3 binding to the NOX1 promoter initiates transcription that is dependent on serine phosphorylation (S308). Increased expression of full-length NOX1 (NOX1-L) promotes ROS production which can inhibit PTP activity and increase cyclin D3 levels, leading to enhanced cell cycle traverse through S-phase and increased colon cancer cell proliferation. Human colon cancers, when compared to adjacent uninvolved colonic epithelia, demonstrate significantly higher levels of NOX1 and IL-4R $\alpha$ mRNA, consistent with this model. 
with the inflammatory bowel disease, ulcerative colitis [68]. Thus, we evaluated potential GATA3 binding sites in the HT-29 cell promoter, and found by mutational analysis that the conserved consensus sequence required for the binding of GATA3 to the NOX1 promoter is located at bp $-321 /-315$. These results support the possibility that GATA3 could be important for the regulation of NOX1 expression by pro-inflammatory cytokines [69].

To investigate the clinical relevance of our findings, we examined the relationship between expression levels of NOX1 and IL-4R $\alpha$ in human colorectal cancer surgical specimens and adjacent uninvolved bowel mucosa by real time RT-PCR. At the mRNA level, there was a significant correlation between the two (Figure 8B). This observation was confirmed using a publicly available dataset that examined gene expression in colon cancers and associated normal tissues by expression array profiling [70] (data not shown). These data are consistent with the hypothesis that IL-4 or IL-13, generated in either an autocrine or paracrine fashion or by inflammatory cells, could be involved in activating STAT6-dependent upregulation of NOX1 expression in both colon cancers and adjacent bowel. Our prior results demonstrated that NOXO1 and NOXA1, in addition to NOX1, are also increased in clinical colon cancer specimens [61], facilitating the potential for active NOX1 activity. Because previous studies have documented the ability of NOX1-dependent ROS to produce genetic instability in mammalian cells [71], it is reasonable to suggest that the IL-4- or IL-13mediated upregulation of NOX1 could play a role in the development of the colorectal cancers that occur in patients with inflammatory bowel disease or stimulate the progression of established colonic neoplasms.

In summary, our studies (summarized in Figure 9) demonstrate that the $T_{H} 2$ cytokines IL-4 and IL-13 significantly enhance the transcription of NOX1, leading to the production of substantial amounts of $\mathrm{O}_{2}{ }^{-}$by human colon cancer cells, and that increased NOX1 expression depends on the activation and binding of GATA3 to the NOX1 promoter. Furthermore, NOX1-dependent ROS are actively involved in stimulating tumor cell proliferation that is related, in part, to an increase in cell cycle progression through S-phase. In human colon cancers and adjacent normal tissues, the expression of NOX1 and the Type II IL-4R are significantly correlated. In light of these data, support exists for the possibility that NOX1related ROS, produced as a consequence of IL-4 or IL-13 exposure, may play an important role in the development of a pro-oxidant milieu in the colon, conducive to colorectal carcinogenesis and/or malignant progression. In this context, the development of therapeutic approaches to interdict the pro-oxidant effects of IL-4 or IL-13, through a neutralizing antibody [72], other protein scaffolds [53], or direct inhibition of NOX1 [17] might provide a novel method to interfere with pro-inflammatory oxidative damage in the colon.

\section{MATERIALS AND METHODS}

\section{Materials}

Recombinant human IL-4 (catalog no. 204-IL050) and recombinant human IL-13 (catalog no. 213IL025) were purchased from R \& D systems (Minneapolis, $\mathrm{MN})$. Antibodies: Antibody against human $\beta$-actin (catalog no. A3853) was acquired from Sigma-Aldrich. Antibodies against human GAPDH and Lamin A/C were obtained from Cell Signaling Technology (catalog nos. 5174 and 4777). An antibody raised against human IL$4 \mathrm{R} \alpha$ (catalog no. MAB230) was from R \& D Systems. Human GATA3 antibody was purchased from Santa Cruz Biotechnology (catalog no. sc-269). Human antiphosphoserine antibody (catalog no. ab6639) and a second human IL4R $\alpha$ antibody (catalog no. ab50277) were from Abcam Biochemical. The IL-4R $\alpha$ antibody from Abcam was used for Western analyses; the R\&D antibody was used for studies of IL-4R $\alpha$ inhibition. Human anti-STAT6 antibody (catalog no. 611290) and human anti-phospho STAT6 (pY641; catalog no. 611566) were obtained from BD Biosciences. Antibodies against Bcl-2, caspase 8, procaspase 3 , and cleaved caspase 3 , and cyclins $\mathrm{D}_{1}$ and $\mathrm{D}_{3}$ were obtained from Cell Signaling Technology (catalog nos. 2872, 9746, 9662, 9661, respectively, and the cell cycle regulation antibody sampler kit catalog no. 9932). Anti-ATPase (catalog no. CS3010) and human anti-JAK1 (catalog no. CS3332) antibodies were purchased from Cell Signaling. A mouse monoclonal antibody against NOX1 was raised against a recombinant protein that represented 341 carboxy-terminal amino acids (224-564 amino acid sequence) of the human NOX1 protein, as previously described [73]. Human primers: NOX1 (catalog no. Hs00246589_m1), $\beta$-actin (catalog no. Hs99999903_m1), NOXA1 (catalog no. Hs00611456_g1), NOXO1 (catalog no. Hs00376039_g1), NOX2-5, DUOX1 and DUOX2 (catalog nos. Hs00166163_m1; Hs00571343_CE; Hs00110468_CE; Hs00674976_CE; Hs00719583_CE; Hs00647818_CE), GATA3 (catalog no. Hs00231122_m1), JAK1 (catalog no. Hs01026983_m1), IL-4R $\alpha$ (catalog no. Hs00166237_m1), and STAT6 (catalog no. Hs00598625 m1) were purchased from Applied Biosystems (Foster City, CA). Human IL-4R $\alpha$ siRNA (catalog nos. s3703, s3704), human JAK1 siRNA (catalog nos. s7646, s7647), human STAT6 siRNA (catalog nos. s13541, s13542), and human GATA3 siRNA (catalog nos. s5600, s5601) were also from Applied Biosystems. A Myc-DDK-tagged ORF clone of a GATA-3 plasmid (catalog no. RC511904) and a Myc-DDK-tagged human NADPH oxidase 1 (Nox1-L) construct (catalog no. RC210426) were obtained from Origene Technologies. RNeasy Mini Kits (catalog no. 74104) and the RNeasy Plus Universal Mini Kit (catalog no. 73404) were from QIAGEN. TaqMan Universal PCR 
mix (catalog no. 4364340) was from Applied Biosystems. The Dual-Luciferase Reporter Assay System was from Promega Corporation. The FITC BrdU Flow Kit (catalog no. 559619) was from BD Biosciences. The QuikChange II XL Site-Directed Mutagenesis Kit was from Stratagene (catalog no. 200521). The Superoxide Anion Assay Kit was from Sigma-Aldrich (catalog no. CS1000). Protein A/G PLUS-Agarose (catalog no. sc2003), chromatin immunoprecipitation (ChIP) assay lysis buffer (catalog no. sc45000), lysis buffer high salt (catalog no. sc45001), wash buffer (catalog no. sc45002), and elution buffer (catalog no. sc45003) were from Santa Cruz Biotechnology. The NOX1 promoter construct was kindly provided by Dr. Senlin Li (Department of Medicine, University of Texas Health Science Center, San Antonio, TX). The identity of the promoter was confirmed by sequencing.

\section{Tumor cell culture and in vitro growth assay}

HT-29 human colon cancer cells were obtained from the American Type Culture Collection (ATCC, Manassas, VA) and grown in McCoy's 5A medium (Lonza, Walkersville, MD) with 10\% FBS (Gemini Bio-products, West Sacramento, CA). A stable clone of HT-29 cells that expresses a scrambled NOX1 shRNA (SC cells), and two independent, clonal HT-29 cell lines that express a NOX1 shRNA producing approximately $65-70 \%$ (Si6/G6 cells) or $>90 \%$ (6A cells) reduction in NOX1 expression have been described previously [16]. WiDr, SW403, NCI-H508, and DLD-1 human colon cancer cell lines were also obtained from ATCC and were propagated in RPMI-1640 medium (GE Healthcare Life Sciences, Logan, UT) with 10\% FBS. Tumor cells were cultured in a humidified incubator at 37 ${ }^{\circ} \mathrm{C}$ in an atmosphere of $5 \% \mathrm{CO}_{2}$ in air. Parental HT-29 tumor cells, and the SC, Si6/G6, and 6A clonal variants were seeded into $60 \mathrm{~mm}$ tissue culture plates (Sarstedt, Inc., Newton, NC) at a concentration of $1 \times 10^{5}$ cells/plate in McCoy's 5A medium containing 10\% FBS. After one day in culture, cells adherent to the plates were treated with $50 \mathrm{ng} / \mathrm{ml}$ of IL-4 or IL-13; cell proliferation was determined by counting each day using a Cellometer Auto T4 Cell Counter (Nexcelom Bioscience, Lawrence, MA). Every sample was measured in triplicate; the data represent a minimum of three independent experiments.

\section{IL-4Ro inhibition}

HT-29 cells were placed in $60 \mathrm{~mm}$ tissue culture plates and grown overnight; starved cells that had been grown in medium without serum for $12 \mathrm{~h}$ were then pre-treated with IL-4R $\alpha$ antibody ( $\mathrm{R} \& \mathrm{D}$ systems, Minneapolis, MN) for $30 \mathrm{~min}$ at concentrations of 1 or $10 \mathrm{ng} / \mathrm{ml}$. IL-4 was then added into the medium for $24 \mathrm{~h}$ at a final concentration of $50 \mathrm{ng} / \mathrm{ml}$. Three independent experiments were conducted.

\section{RNA isolation and real-time RT-PCR}

Total cellular RNA was prepared using RNeasy Mini Kits (Qiagen, Valencia, CA). Two micrograms of total RNA was treated with DNAse and reverse transcribed using Superscript II reverse transcriptase (Gibco-BRL, Rockville, MD). $20 \mu \mathrm{l}$ of cDNA was diluted into $100 \mu \mathrm{l}$ with water; $2 \mu$ l of the cDNA solution was used in every reaction. The integrity of all cDNA preparations was verified by amplifying $\beta$-actin as a control gene. Real time RT-PCR was performed on 384-well plates in a 20 $\mu \mathrm{l}$ reaction system containing $1 \mu \mathrm{l}$ of primer mixture, 7 $\mu \mathrm{l}$ of $\mathrm{H}_{2} \mathrm{O}, 10 \mu \mathrm{l}$ of TaqMan $2 \times$ PCR mixture, and $2 \mu \mathrm{l}$ of diluted cDNA. The PCR was carried out using default fast thermal cycling conditions $\left(50{ }^{\circ} \mathrm{C} \mathrm{UNG}\right.$ activation for $2 \mathrm{~min}, 95^{\circ} \mathrm{C}$ enzyme activation for $10 \mathrm{~min}, 40$ cycles of $15 \mathrm{~s} 95^{\circ} \mathrm{C}$ denaturation, and $1 \mathrm{~min}$ for $60^{\circ} \mathrm{C}$ annealing/ extension). Fluorescence was detected with the ABI 7900HT sequence detection system (Applied Biosystems, Foster City, CA). Triplicate determinations were performed for each sample; three separate experiments were performed for each gene of interest.

\section{Detection of human NOX1 mRNA}

PCR primers (designed for both the NOX1-L and NOX1-S transcripts or designed for the NOX1-L transcript alone) were used to detect human NOX1 mRNA. NOX1-L/NOX1-S: 5'-GGGCTTTCGAACAACAATAT-3' and 5'-CGAGGGCCACATAAGAAAA-3'. NOX1-L: 5'-TGGAGGAATTAGGCAAAGTG-3', and 5'-CAAAGGAGGTTTTCTGTTTCAG-3'. The NOX1-L/ NOX1-S primer set was designed to produce 502- or 355-base pair amplicons depending upon the presence (NOX1-L) or absence (NOX1-S) of exon 11 in NOX1. The NOX1-L primer set was designed to amplify a 141-base pair amplicon from NOX1-L transcripts. The Myc-DDKtagged human NOX1-L construct (Origene, Rockville, MD) was used as a positive control in our experiments. $2 \mu \mathrm{l}$ of the cDNA solution was used in standard PCR conditions including $95{ }^{\circ} \mathrm{C}$ initial denaturation for $30 \mathrm{sec}$; every cycle had a $30 \mathrm{sec} 95^{\circ} \mathrm{C}$ denaturation, $30 \mathrm{sec} 55$ ${ }^{\circ} \mathrm{C}$ annealing, and $68^{\circ} \mathrm{C}$ extension; the final extension was performed at $68^{\circ} \mathrm{C}$ for $5 \mathrm{~min}$. All cell line samples underwent 30 cycles of amplification. Three separate experiments were performed.

\section{Western analysis}

Tumor cells were washed with 1 x PBS (Lonza, Walkersville, MD) three times. Whole cell lysates were prepared in $1 \mathrm{x}$ RIPA lysis buffer (Millipore/Upstate Biotechnology, Temecula, CA) supplemented with 1 tablet of complete mini protease inhibitor and 1 tablet 
of PhosStop phosphatase inhibitor mix, both from Roche (Indianapolis, IN). After quantitation of protein levels using the BCA protein assay (Thermo Scientific, Rockford, IL), equal amounts (50-100 $\mu \mathrm{g})$ of protein were loaded on 4-20\% TRIS/glycine gels (Invitrogen, Carlsbad, CA) and transferred to nitrocellulose membranes using the iBlot ${ }^{\mathrm{TM}}$ Dry Blotting System (Invitrogen, Carlsbad, CA). Membranes were blocked with 5\% non-fat dry milk in TBST (TBS, Quality Biologicals, Gaithersburg, MD; containing $0.1 \%$ Tween 20 ) and incubated with a $1: 500$ 5000 dilution of a primary antibody overnight at $4{ }^{\circ} \mathrm{C}$. The membranes were then washed with TBST and incubated with the appropriate horseradish peroxidase-conjugated secondary antibody (Santa Cruz Biotechnology, Inc. Santa Cruz, CA) using 1:3000 dilutions for $1 \mathrm{~h}$ at room temperature. Specific antibody binding was detected using a chemiluminescence detection system (GE/Amersham Biosciences, UK). Subcellular fractionation of tumor cells was performed as previously described [73].

\section{Superoxide anion assay}

Superoxide anion $\left[\mathrm{O}_{2}^{--}\right]$was detected using a luminol-based Superoxide Anion Assay Kit (Sigma). Human colon cancer cell lines, including HT-29 (parental and clonal variants as described above), WiDr, or DLD-1 cells were treated with PBS or IL-4/IL-13 (50ng/ml) for $24 \mathrm{~h}$. Following cytokine or PBS exposure, tumor cells were resuspended in $1 \mathrm{ml}$ of fresh medium and counted using the Cellometer. Collected cells were resuspended in assay medium at a concentration of $1 \times 10^{6}$ cells $/ 100 \mu$ l. Following the manufacturer's instructions, each well of a 96-well plate contained a final volume of $200 \mu \mathrm{l}$; the experimental wells (for cytokine or PBS exposed cells) had $89 \mu \mathrm{l}$ of assay buffer, $5 \mu \mathrm{l}$ of luminol solution, $5 \mu \mathrm{l}$ of enhancer solution, and $1 \mu \mathrm{l}$ of a $40 \mu \mathrm{M}$ working stock of phorbol 12-myristate 13-acetate (PMA); control wells were identical except that they lacked PMA and contained $90 \mu \mathrm{l}$ of assay buffer. Both cytokine-exposed and control cells were also tested in the presence of superoxide dismutase ( $1 \mu \mathrm{l}$ of a 4 units/ $\mu 1$ stock solution). The reaction components were added to the 96-well plates and mixed by pipetting. The reaction was started by adding 100 $\mu 1$ of the cell suspension in assay medium to each well. Luminescence was detected at $37{ }^{\circ} \mathrm{C}$ using a GloMax ${ }^{\circledR}$ Microplate Luminometer (Promega BioSciences, San Luis Obispo, CA) with measurements taken every 2 min during a $2 \mathrm{~h}$ period of observation. Every sample was measured in triplicate; the data represent a minimum of three independent experiments.

\section{Determination of intracellular reactive oxygen production by flow cytometry}

medium $2 \mathrm{~h}$ before the determination of ROS production. Tumor cells were trypsinized and counted; $1 \times 10^{6}$ cells were resuspended in $1 \mathrm{ml}$ of PBS containing $5 \mu \mathrm{M}$ of the redox-sensitive dye $\mathrm{CM}-\mathrm{H}_{2}$-DCFDA (Invitrogen, catalog number C6827), and incubated in the dark for $30 \mathrm{~min}$ at $37{ }^{\circ} \mathrm{C}$. For short term IL-4 exposure $(5 \mathrm{~min}), 50 \mathrm{ng} / \mathrm{ml}$ of IL-4 was added to the cells, and the mixture was incubated in the dark for an additional $5 \mathrm{~min}$. Fluorescence was quickly recorded on the FL-1 channel of a FACS Aria flow cytometer (BD Bioscience) and analyzed using FlowJo ${ }^{\circledR}$ Software.

\section{Chromatin immunoprecipitation}

Chromatin immunoprecipitation [ChIP] analysis was performed for HT-29 cells cultured for $24 \mathrm{~h}$ with or without IL-4 treatment; following exposure to IL-4 or vehicle, tumor cells were cross-linked for $10 \mathrm{~min}$ with formaldehyde at room temperature; the cross-linking was stopped by adding glycine at a final concentration of $125 \mathrm{mM}$. Cells were washed and lysed to collect nuclei. Nuclei were resuspended in high salt buffer and sonicated on ice three times (15 s each) using a Sonic Dismembrator Model 100 sonicator (Fisher Scientific) at level 3 to shear chromatin at an average length of $\approx$ 600 bp. Samples were washed with a protein A/G agarose slurry. The supernatant fraction was collected after centrifugation at $12,000 \times \mathrm{g}$ for $10 \mathrm{~min}$. Twenty percent of the total supernatant was used as the input control. The remaining eighty percent of the supernatant was used for immunoprecipitation; $5 \mu \mathrm{g}$ of antibody (either anti-GATA3 or isotype-matched IgG) was incubated with the samples at $4{ }^{\circ} \mathrm{C}$ overnight. DNA was purified and used in quantitative PCR reactions (SYBR Green qPCR SuperMix, Invitrogen); the primers employed were as follows: 5'CCTCCCTACTTCTCCTGAAGTAATC-3' and 5'- GAGAACCACAAGGGTTTTACCTGT-3'.

\section{Immunoprecipitation}

Whole cell lysates were prepared in $1 \mathrm{x}$ RIPA lysis buffer (Millipore/Upstate Biotechnology, Temecula, CA) in the presence of 1 tablet of Complete Mini protease inhibitor and 1 tablet of PhosStop phosphatase inhibitor mix, both from Roche (Indianapolis, IN). Lysates were centrifuged at $4{ }^{\circ} \mathrm{C}$ for $10 \mathrm{~min}$ at $12,000 \mathrm{rpm}$ in an Eppendorf microcentrifuge to remove cellular debris. After pre-washing with protein $\mathrm{A} / \mathrm{G}$ agarose, samples were then immunoprecipitated with $2 \mu \mathrm{g}$ of anti-GATA3 antibody using protein $\mathrm{A} / \mathrm{G}$ agarose slurry in the presence of protease inhibitors. The same amount of IgG was used as a negative control. Western analysis was performed using anti-GATA3 and anti-phosphoserine antibodies.

HT-29 cells were treated with $50 \mathrm{ng} / \mathrm{ml}$ of IL-4 for $96 \mathrm{~h}$. DPI (200 $\mathrm{nM})$ was added to the tissue culture 


\section{FITC BrdU flow cytometry}

BrdU incorporation into DNA was detected using an FITC BrdU Flow Kit (BD Biosciences, San Jose, CA). Colon cancer cells were labeled by adding BrdU solution into culture medium to produce a final BrdU concentration of $10 \mu \mathrm{M}$. The labeled cells were incubated for $1 \mathrm{~h}$ at $37^{\circ} \mathrm{C}$, collected by trypsinization, centrifuged, and fixed in BD Cytofix/Cytoperm Buffer. Cells were then permeabilized with BD Cytoperm Permeabilization Buffer Plus, and fixed again with BD Cytofix/Cytoperm Buffer. BrdU epitopes were exposed by re-suspending the tumor cells in DNase (30 $\mu \mathrm{g}$ DNase $/ 10^{6}$ cells) at $37^{\circ} \mathrm{C}$ for $1 \mathrm{~h}$. BrdU was stained with a fluorochrome-conjugated anti-BrdU antibody (1:50 dilution, room temperature for $20 \mathrm{~min}$ ). Total DNA was stained with $20 \mu \mathrm{l}$ of a 7-aminoactinomycin D [7-AAD] solution (provided with the Kit) using a $5 \mathrm{~min}$ incubation. Tumor cells were then resuspended in $1 \mathrm{ml}$ PBS. Stained cells were subsequently analyzed using a FACS Calibur Flow Cytometer (Becton Dickinson, San Jose, CA) equipped with a 488-nm laser capable of detecting both 7-AAD and FITC.

\section{Protein tyrosine phosphatase activity}

Protein tyrosine phosphatase [PTP] activity was detected using PTP Assay Kit 1 (EMD Millipore, catalog number 17-125). Cells $\left(1 \times 10^{5}\right)$ were placed in $60 \mathrm{~mm}$ plates; $50 \mathrm{ng} / \mathrm{ml}$ of IL-4 was added to culture medium for 24 or $96 \mathrm{~h}$ of treatment. Cells were scraped from the dishes with $0.3 \mathrm{ml}$ of phosphatase extraction buffer containing $20 \mathrm{mM}$ imidazole- $\mathrm{HCl}, 2 \mathrm{mM}$ EDTA, 2mM EGTA, $\mathrm{pH}$ 7.0 that included $10 \mu \mathrm{g} / \mathrm{ml}$ each of aprotinin, leupeptin, antipain, soybean trypsin inhibitor, $1 \mathrm{mM}$ benzamidine, and $1 \mathrm{mM}$ PMSF. Cells were centrifuged at $2000 \times \mathrm{g}$ for $5 \mathrm{~min}$. Supernatants were used for phosphatase activity assays; $5 \mu \mathrm{l}$ of $1 \mathrm{mM}$ phosphopeptide was added to $250 \mathrm{ng}$ protein for each sample. Enzyme reactions were performed in a final volume of $25 \mu \mathrm{l}$ in 96 -well microtiter plates incubated at room temperature for $15 \mathrm{~min}$. Color was developed by addition of $100 \mu 1$ of Malachite Green Solution into each sample for $15 \mathrm{~min}$ at room temperature. Absorbance was measured at a wavelength of $620 \mathrm{~nm}$ in a microtiter plate reader. Phosphate release was determined by comparing the measured absorbance to a standard curve over a range of 0-2000 pmoles. Each value in the figure represents the mean $\pm \mathrm{SD}$ of triplicate experiments.

\section{Construction of point mutations}

Point mutations in the human NOX1 promoter and in a human GATA3 construct were obtained using the Quikchange XL mutagenesis kit (Stratagene, La Jolla, CA) following the manufacturer's specifications. For NOX1 promoter construct mutations, the following primer sets were used:

Primer1F

(5'-AGGGGAAGAAGGAAGATGTGATCA

GGGAGGGAAATACAAAGAGCTTTAAGATACTG-3')

Primer 1R

(5'-GATCACATCTTCCTT

CTTCCCCTCCTCTACCCCACCGGATGTAATCA-3')

Primer2F

(5'-TTAGGTCATGTTAAGGAGATGATGAGAGA

GAATATTTTCATCCAAGAATGTTGCTATTTC-3')

Primer2R

(5'-CTCATCATCTCCTTAACATGACCTAATGTG

AAGCATTGCCTTCCTAGATA AAAGA-3')

Primer $3 \mathrm{~F}$

(5'-GTTCTCATAGGAAGGGCTGGTCTATCTAA

GCTGGAAGCACAGTT CTGTCC-3’)

Primer 3R

(5'-ACCAGCCCTTCCTATGAGAACCACAAG

GGTTTTACCTGTG GGGATT-3')

Primer 4F

(5'-CTATCTAAGCTGGAAGCACAGTTCTGT

CCAGAGAAGCTCGAGA TCTGCG-3')

Primer 4R

(5'-AGAACTGTGCTTCCAGCTTAGATAG

ACCAGCCCTTCCTATGAGA ACCACA-3')

For the GATA3 S308A point mutant:

(F:5'-CAAGCCCAAGCGAAGGCTGGCGgC

AGCAAGGAGAGCAGGG-3';R:5'

CCCTGCTCTCCTTGCTGCCGc

CAGCCTTCGCTTGGGCTTG-3’).

\section{Transient transfection and luciferase assay}

Tumor cells were collected with trypsin and counted; $1 \times 10^{6}$ cells were resuspended in $100 \mu$ of transfection reagent solution (Lonza Amaxa transfection kit, Kit R, Program W-017 for HT-29 cells; Kit T, Program B-024 for WiDr cells) and then transferred to a new tube; for each transfection, $2 \mu \mathrm{g}$ of plasmid DNA was added and mixed. Cells were electroporated using the Amaxa Nucleofector Device (Lonza, ME). Following transfection, cells were transferred from $100 \mu$ l aluminum electrode cuvettes into $60 \mathrm{~mm}$ tissue culture plates, and propagated at $37{ }^{\circ} \mathrm{C}$ overnight in normal tissue culture medium (McCoy's 5A medium with 10\% FBS for HT-29 cells; RPMI-1640 medium with 10\% FBS for WiDr cells). Fresh tissue culture medium was then exchanged following overnight culture. Firefly/Renilla luciferase were detected on the second day $(24 \mathrm{~h})$ and third day ( $48 \mathrm{~h}$ ) following transfection using the Dual-Luciferase Reporter Assay System (Promega BioSciences, San Luis Obispo, CA) according to the manufacturer's recommendations. 


\section{NOX1 and IL-4R $\alpha$ mRNA expression levels in human colon cancer samples}

NOX1 and IL-4R $\alpha$ gene expression determinations from human colon cancers and adjacent normal tissues were accessed from the publicly available portion of the Oncomine $^{\mathrm{TM}}$ website (NOX1: 206418 at; IL-4R:203233 at). The data for these NOX1 expression levels in human colon cancers had been deposited in the NCBI Gene Expression Omnibus (Series GSE20916). Fresh, pathologically-confirmed primary human colon cancer tissues and adjacent normal tissues were obtained from surgical specimens by the National Cancer Institutesupported Cooperative Human Tissue Network (Eastern, Western, Mid-Western, and Mid-Atlantic Divisions) in compliance with the office of human subjects research at the National Institutes of Health. Specimens were selected without regard to age, race/ancestry, or sex and were acquired from patients who had not received chemotherapy or radiation therapy prior to surgical intervention. Tumors were preserved by snap-freezing in liquid nitrogen within 60 minutes of surgery. Tissues ranging in size from 300 to $2200 \mathrm{mg}$ were homogenized on ice; RNA was isolated utilizing the RNeasy Plus Universal Mini Kits (Qiagen, Valencia, CA, catalog number 73404) according to the manufacturer's protocol. cDNA synthesis and RT-PCR were performed as described above.

\section{Statistical analysis}

Results are expressed as the mean \pm standard deviation from at least triplicate experiments. Statistical differences between mean values of control and treated samples were assessed using Student's $t$ test; $P<0.05$ was considered statistically significant. Significance levels were designated as $*=P<0.05, * *=P<0.01$, and $* * *=$ $P<0.001$ throughout.

\section{Abbreviations}

NOX, NADPH oxidase; DUOX, dual oxidase; ROS, reactive oxygen species; IFN- $\gamma$, interferon- $\gamma$; TNF- $\alpha$, tumor necrosis factor- $\alpha$; IL-4, interleukin-4; DPI, diphenylene iodonium; DTI, 2-di-thienyl-iodonium; IL-13, interleukin-13; MAPK, mitogen activated protein kinase; $\mathrm{T}_{\mathrm{H}} 2, \mathrm{~T}$ helper type 2; IL-4R $\alpha$, Type II IL-4 receptor; PMA, phorbol myristate acetate; SOD, superoxide dismutase; siRNA, small interfering RNA; $\mathrm{H}_{2}$-DCFDA, 2', 7'-dichlorodihydrofluorescein diacetate; 7-AAD, 7-aminoactinomycin D; CHIP, chromatin immunoprecipitation; PTP, protein tyrosine phosphatase

\section{ACKNOWLEDGMENTS AND FUNDING}

This work was supported by the Division of Cancer Treatment and Diagnosis and the Center for Cancer Research, National Cancer Institute, National Institutes of Health; the work was also conducted, in part, under Contract No. HHSN26120008000001E. The content of this publication does not necessarily reflect the views or policies of the Department of Health and Human Services, nor does mention of trade names, commercial products, or organizations imply endorsement by the U.S. Government.

\section{CONFLICTS OF INTEREST}

There are no conflicts to declare.

\section{REFERENCES}

1. Doroshow JH. Redox modulation of chemotherapy-induced tumor cell killing and normal tissue toxicity. J Natl Cancer Inst. 2006; 98: 223-5.

2. Rhee SG. Cell signaling. H2O2, a necessary evil for cell signaling. Science. 2006; 312: 1882-3.

3. Forman HJ, Maiorino M, Ursini F. Signaling functions of reactive oxygen species. Biochemistry. 2010; 49: 835-42.

4. Arnold RS, Shi J, Murad E, Whalen AM, Sun CQ, Polavarapu R, Parthasarathy S, Petros JA, Lambeth JD. Hydrogen peroxide mediates the cell growth and transformation caused by the mitogenic oxidase nox 1 . Proc Natl Acad Sci USA. 2001; 98: 5550-5.

5. North S, Moenner M, Bikfalvi A. Recent developments in the regulation of the angiogenic switch by cellular stress factors in tumors. Cancer Lett. 2005; 218: 1-14.

6. Arbiser JL, Petros J, Klafter R, Govindajaran B, McLaughlin ER, Brown LF, Cohen C, Moses M, Kilroy $\mathrm{S}$, Arnold RS, Lambeth JD. Reactive oxygen generated by Nox1 triggers the angiogenic switch. Proc Natl Acad Sci USA. 2002; 99: 715-20.

7. Colotta F, Allavena P, Sica A, Garlanda C, Mantovani A. Cancer-related inflammation, the seventh hallmark of cancer: links to genetic instability. Carcinogenesis. 2009; 30: 1073-81.

8. Wu Y, Antony S, Meitzler JL, Doroshow JH. Molecular mechanisms underlying chronic inflammation-associated cancers. Cancer Lett. 2014; 345: 164-73.

9. Bedard K, Krause KH. The NOX family of ROS-generating NADPH oxidases: physiology and pathophysiology. Physiol Rev. 2007; 87: 245-313.

10. Jiang F, Zhang Y, Dusting GJ. NADPH oxidase-mediated redox signaling: roles in cellular stress response, stress tolerance, and tissue repair. Pharmacol Rev. 2011; 63: 21842.

11. Brandes RP, Weissmann N, Schroder K. Nox family NADPH oxidases: Molecular mechanisms of activation. 
Free Radic Biol Med. 2014; 76C: 208-26.

12. Suh YA, Arnold RS, Lassegue B, Shi J, Xu X, Sorescu $\mathrm{D}$, Chung $\mathrm{AB}$, Griendling KK, Lambeth JD. Cell transformation by the superoxide-generating oxidase Mox1. Nature. 1999; 401: 79-82.

13. Sadok A, Bourgarel-Rey V, Gattacceca F, Penel C, Lehmann M, Kovacic H. Nox1-dependent superoxide production controls colon adenocarcinoma cell migration. Biochim Biophys Acta. 2008; 1783: 23-33.

14. Diaz B, Shani G, Pass I, Anderson D, Quintavalle M, Courtneidge SA. Tks5-dependent, Nox-mediated generation of reactive oxygen species is necessary for invadopodia formation. Sci Signal. 2009; 2: ra53.

15. Wang R, Dashwood WM, Nian H, Lohr CV, Fischer KA, Tsuchiya N, Nakagama H, Ashktorab H, Dashwood RH. NADPH oxidase overexpression in human colon cancers and rat colon tumors induced by 2-amino-1-methyl-6phenylimidazo[4,5-b]pyridine (PhIP). Int J Cancer. 2011; 128: 2581-90.

16. Juhasz A, Markel S, Gaur S, Liu H, Jiang G, Wu X, Antony S, Wu Y, Melillo G, Meitzler JL, Haines DC, Butcher D, Roy $\mathrm{K}$, et al. NADPH oxidase 1 supports proliferation of colon cancer cells by modulating reactive oxygen species-dependent signal transduction. J Biol Chem. 2017; 292:7866-7887. doi: 10.1074/jbc.M116.768283.

17. Doroshow JH, Gaur S, Markel S, Lu J, van Balgooy J, Synold TW, Xi B, Wu X, Juhasz A. Effects of iodoniumclass flavin dehydrogenase inhibitors on growth, reactive oxygen production, cell cycle progression, NADPH oxidase 1 levels, and gene expression in human colon cancer cells and xenografts. Free Rad Bio Med. 2013; 57: 162-75.

18. Geiszt M, Lekstrom K, Brenner S, Hewitt SM, Dana R, Malech HL, Leto TL. NAD(P)H oxidase 1, a product of differentiated colon epithelial cells, can partially replace glycoprotein 91phox in the regulated production of superoxide by phagocytes. J Immunol. 2003; 171: 299-306.

19. Alam A, Leoni G, Wentworth CC, Kwal JM, Wu H, Ardita CS, Swanson PA, Lambeth JD, Jones RM, Nusrat A, Neish AS. Redox signaling regulates commensal-mediated mucosal homeostasis and restitution and requires formyl peptide receptor 1. Mucosal Immunol. 2014; 7: 645-655.

20. Leoni G, Alam A, Neumann PA, Lambeth JD, Cheng G, McCoy J, Hilgarth RS, Kundu K, Murthy N, Kusters D, Reutelingsperger C, Perretti M, Parkos CA, et al. Annexin A1, formyl peptide receptor, and NOX1 orchestrate epithelial repair. J Clin Invest. 2013; 123: 443-54.

21. Esworthy RS, Kim BW, Chow J, Shen B, Doroshow JH, Chu FF. Nox1 causes ileocolitis in mice deficient in glutathione peroxidase-1 and -2. Free Radic Biol Med. 2014; 68: 315-25.

22. Kamizato M, Nishida K, Masuda K, Takeo K, Yamamoto Y, Kawai T, Teshima-Kondo S, Tanahashi T, Rokutan $\mathrm{K}$. Interleukin 10 inhibits interferon gamma- and tumor necrosis factor alpha-stimulated activation of NADPH oxidase 1 in human colonic epithelial cells and the mouse colon. J Gastroenterol. 2009; 44: 1172-84.

23. Ullman TA, Itzkowitz SH. Intestinal inflammation and cancer. Gastroenterology. 2011; 140: 1807-16.

24. Cheng G, Diebold BA, Hughes Y, Lambeth JD. Nox1dependent reactive oxygen generation is regulated by Rac1. J Biol Chem. 2006; 281: 17718-26.

25. Gianni D, Bohl B, Courtneidge SA, Bokoch GM. The involvement of the tyrosine kinase $\mathrm{c}-\mathrm{Src}$ in the regulation of reactive oxygen species generation mediated by NADPH oxidase-1. Mol Biol Cell. 2008; 19: 2984-94.

26. Doroshow JH, Juhasz A, Ge Y, Holbeck S, Lu J, Antony S, Wu Y, Jiang G, Roy K. Antiproliferative mechanisms of action of the flavin dehydrogenase inhibitors diphenylene iodonium and di-2-thienyliodonium based on molecular profiling of the NCI-60 human tumor cell panel. Biochem Pharmacol. 2012; 83: 1195-207.

27. Kelly-Welch AE, Hanson EM, Boothby MR, Keegan AD. Interleukin-4 and interleukin-13 signaling connections maps. Science. 2003; 300: 1527-8.

28. Terabe M, Park JM, Berzofsky JA. Role of IL-13 in regulation of anti-tumor immunity and tumor growth. Cancer Immunol Immunother. 2004; 53: 79-85.

29. Li-Weber M, Krammer PH. Regulation of IL4 gene expression by T cells and therapeutic perspectives. Nat Rev Immunol. 2003; 3: 534-43.

30. Kaklamanis L, Gatter KC, Mortensen N, Harris AL. Interleukin-4 receptor and epidermal growth factor receptor expression in colorectal cancer. Br J Cancer. 1992; 66: 7126.

31. Koller FL, Hwang DG, Dozier EA, Fingleton B. Epithelial interleukin-4 receptor expression promotes colon tumor growth. Carcinogenesis. 2010; 31: 1010-7.

32. Barderas R, Bartolome RA, Fernandez-Acenero MJ, Torres S, Casal JI. High expression of IL-13 receptor alpha2 in colorectal cancer is associated with invasion, liver metastasis, and poor prognosis. Cancer Res. 2012; 72: 2780-90.

33. Myers JN, Yasumura S, Suminami Y, Hirabayashi H, Lin W, Johnson JT, Lotze MT, Whiteside TL. Growth stimulation of human head and neck squamous cell carcinoma cell lines by interleukin 4 . Clin Cancer Res. 1996; 2: 127-35.

34. Hosoyama T, Aslam MI, Abraham J, Prajapati SI, Nishijo K, Michalek JE, Zarzabal LA, Nelon LD, Guttridge DC, Rubin BP, Keller C. IL-4R drives dedifferentiation, mitogenesis, and metastasis in rhabdomyosarcoma. Clin Cancer Res. 2011; 17: 2757-66.

35. Formentini A, Prokopchuk O, Strater J, Kleeff J, Grochola LF, Leder G, Henne-Bruns D, Korc M, Kornmann M. Interleukin-13 exerts autocrine growth-promoting effects on human pancreatic cancer, and its expression correlates with a propensity for lymph node metastases. Int J Colorectal Dis. 2009; 24: 57-67. 
36. Prokopchuk O, Liu Y, Henne-Bruns D, Kornmann M. Interleukin-4 enhances proliferation of human pancreatic cancer cells: evidence for autocrine and paracrine actions. Br J Cancer. 2005; 92: 921-8.

37. Roca H, Craig MJ, Ying C, Varsos ZS, Czarnieski P, Alva AS, Hernandez J, Fuller D, Daignault S, Healy PN, Pienta KJ. IL-4 induces proliferation in prostate cancer PC3 cells under nutrient-depletion stress through the activation of the JNK-pathway and survivin up-regulation. J Cell Biochem. 2012; 113: 1569-80.

38. Li Z, Jiang J, Wang Z, Zhang J, Xiao M, Wang C, Lu Y, Qin Z. Endogenous interleukin-4 promotes tumor development by increasing tumor cell resistance to apoptosis. Cancer Res. 2008; 68: 8687-94.

39. Todaro $M$, Lombardo $Y$, Francipane MG, Alea MP, Cammareri P, Iovino F, Di Stefano AB, Di Bernardo C, Agrusa A, Condorelli G, Walczak H, Stassi G. Apoptosis resistance in epithelial tumors is mediated by tumor-cellderived interleukin-4. Cell Death Differ. 2008; 15: 762-72.

40. Hallett MA, Venmar KT, Fingleton B. Cytokine stimulation of epithelial cancer cells: the similar and divergent functions of IL-4 and IL-13. Cancer Res. 2012; 72: 6338-43.

41. Sharma P, Chakraborty R, Wang L, Min B, Tremblay ML, Kawahara T, Lambeth JD, Haque SJ. Redox regulation of interleukin-4 signaling. Immunity. 2008; 29: 551-64.

42. Aman MJ, Tayebi N, Obiri NI, Puri RK, Modi WS, Leonard WJ. cDNA cloning and characterization of the human interleukin 13 receptor alpha chain. J Biol Chem. 1996; 271: 29265-70.

43. Minty A, Chalon P, Derocq JM, Dumont X, Guillemot JC, Kaghad M, Labit C, Leplatois P, Liauzun P, Miloux B, Minty C, Casellas P, Loison G, et al. Interleukin-13 is a new human lymphokine regulating inflammatory and immuneresponses. Nature. 1993; 362: 248-50.

44. Banfi B, Clark RA, Steger K, Krause KH. Two novel proteins activate superoxide generation by the NADPH oxidase NOX1. J Biol Chem. 2003; 278: 3510-3.

45. Wu Y, Antony S, Juhasz A, Lu J, Ge Y, Jiang G, Roy K, Doroshow JH. Up-regulation and sustained activation of Stat1 are essential for interferon-gamma (IFN-gamma)induced dual oxidase 2 (Duox2) and dual oxidase A2 (DuoxA2) expression in human pancreatic cancer cell lines. J Biol Chem. 2011; 286: 12245-56.

46. Di Stefano AB, Iovino F, Lombardo Y, Eterno V, Hoger T, Dieli F, Stassi G, Todaro M. Survivin is regulated by interleukin-4 in colon cancer stem cells. J Cell Physiol. 2010; 225: 555-61.

47. Harper RW, Xu CH, Soucek K, Setiadi H, Eiserich JP. A reappraisal of the genomic organization of human Nox1 and its splice variants. Arch Biochem Biophys. 2005; 435: 323 30 .

48. Murata T, Noguchi PD, Puri RK. IL-13 induces phosphorylation and activation of JAK2 Janus kinase in human colon carcinoma cell lines: similarities between IL-4 and IL-13 signaling. J Immunol. 1996; 156: 2972-8.

49. Yamashita M, Shinnakasu R, Asou H, Kimura M, Hasegawa A, Hashimoto K, Hatano N, Ogata M, Nakayama T. Ras-ERK MAPK cascade regulates GATA3 stability and Th2 differentiation through ubiquitin-proteasome pathway. J Biol Chem. 2005; 280: 29409-19.

50. Bouchard MF, Taniguchi H, Viger RS. Protein kinase A-dependent synergism between GATA factors and the nuclear receptor, liver receptor homolog-1, regulates human aromatase (CYP19) PII promoter activity in breast cancer cells. Endocrinology. 2005; 146: 4905-16.

51. Maneechotesuwan K, Yao X, Ito K, Jazrawi E, Usmani OS, Adcock IM, Barnes PJ. Suppression of GATA-3 nuclear import and phosphorylation: a novel mechanism of corticosteroid action in allergic disease. Plos Med. 2009; 6: e1000076. doi: 10.1371/journal.pmed.1000076.

52. Fuss IJ, Joshi B, Yang Z, Degheidy H, Fichtner-Feigl S, de Souza H, Rieder F, Scaldaferri F, Schirbel A, Scarpa M, West G, Yi C, Xu L, et al. IL-13Ralpha2-bearing, type II NKT cells reactive to sulfatide self-antigen populate the mucosa of ulcerative colitis. Gut. 2014; 63: 1728-36.

53. Kasaian MT, Page KM, Fish S, Brennan A, Cook TA, Moreira K, Zhang M, Jesson M, Marquette K, Agostinelli R, Lee J, Williams CM, Tchistiakova L, et al. Therapeutic activity of an interleukin-4/interleukin-13 dual antagonist on oxazolone-induced colitis in mice. Immunology. 2014; 143: 416-27.

54. Gologan S, Iacob R, Iancu D, Iacob S, Cotruta B, Vadan R, Catuneanu AM, Constantinescu I, Barbarii L, Gheorghe C, Diculescu M. Inflammatory gene expression profiles in Crohn's disease and ulcerative colitis: a comparative analysis using a reverse transcriptase multiplex ligationdependent probe amplification protocol. J Crohns Colitis. 2013; 7: 622-30.

55. Van KC, Gauldie J, Collins SM. Proinflammatory properties of IL-4 in the intestinal microenvironment. Am J Physiol Gastrointest Liver Physiol. 2005; 288: G111-G117.

56. Francipane MG, Alea MP, Lombardo $\mathrm{Y}$, Todaro M, Medema JP, Stassi G. Crucial role of interleukin-4 in the survival of colon cancer stem cells. Cancer Res. 2008; 68: 4022-5.

57. Formentini A, Braun P, Fricke H, Link KH, HenneBruns D, Kornmann M. Expression of interleukin-4 and interleukin-13 and their receptors in colorectal cancer. Int J Colorectal Dis. 2012; 27: 1369-76.

58. Menon SG, Sarsour EH, Spitz DR, Higashikubo R, Sturm $\mathrm{M}$, Zhang H, Goswami PC. Redox regulation of the G1 to S phase transition in the mouse embryo fibroblast cell cycle. Cancer Res. 2003; 63: 2109-17.

59. Onumah OE, Jules GE, Zhao Y, Zhou L, Yang H, Guo Z. Overexpression of catalase delays G0/G1- to S-phase transition during cell cycle progression in mouse aortic endothelial cells. Free Radic Biol Med. 2009; 46: 1658-67.

60. Ranjan P, Anathy V, Burch PM, Weirather K, Lambeth JD, 
Heintz NH. Redox-dependent expression of cyclin D1 and cell proliferation by Nox 1 in mouse lung epithelial cells. Antioxid Redox Signal. 2006; 8: 1447-59.

61. Juhasz A, Ge Y, Markel S, Chiu A, Matsumoto L, van Balgooy J, Roy K, Doroshow JH. Expression of NADPH oxidase homologues and accessory genes in human cancer cell lines, tumours and adjacent normal tissues. Free Radic Res. 2009; 43: 523-32.

62. Lahm H, Schnyder B, Wyniger J, Borbenyi Z, Yilmaz A, Car BD, Fischer JR, Givel JC, Ryffel B. Growth inhibition of human colorectal-carcinoma cells by interleukin-4 and expression of functional interleukin-4 receptors. Int $\mathrm{J}$ Cancer. 1994; 59: 440-7.

63. Chang TL, Peng X, Fu XY. Interleukin-4 mediates cell growth inhibition through activation of Stat1. J Biol Chem. 2000; 275: 10212-7.

64. Margolin K, Aronson FR, Sznol M, Atkins MB, Gucalp R, Fisher RI, Sunderland M, Doroshow JH, Ernest ML, Mier JW, Dutcher JP, Gaynor ER, Weiss GR. Phase II studies of recombinant human interleukin-4 in advanced renal cancer and malignant melanoma. J Immunother Emphasis Tumor Immunol. 1994; 15: 147-53.

65. Meloche S, Pouyssegur J. The ERK1/2 mitogen-activated protein kinase pathway as a master regulator of the G1- to S-phase transition. Oncogene. 2007; 26: 3227-39.

66. Brewer AC, Sparks EC, Shah AM. Transcriptional regulation of the NADPH oxidase isoform, Nox1, in colon epithelial cells: role of GATA-binding factor(s). Free Radic Biol Med. 2006; 40: 260-74.

67. Valente AJ, Zhou Q, Lu Z, He W, Qiang M, Ma W, Li G, Wang L, Banfi B, Steger K, Krause KH, Clark RA, Li S.
Regulation of NOX1 expression by GATA, HNF-1alpha, and Cdx transcription factors. Free Radic Biol Med. 2008; 44: 430-43.

68. Ohtani K, Ohtsuka Y, Ikuse T, Baba Y, Yamakawa Y, Aoyagi Y, Fujii T, Kudo T, Nagata S, Shimizu T. Increased mucosal expression of GATA-3 and STAT-4 in pediatric ulcerative colitis. Pediatr Int. 2010; 52: 584-9.

69. Zhang Y, Zhang Y, Gu W, Sun B. TH1/TH2 cell differentiation and molecular signals. Adv Exp Med Biol. 2014; 841: 15-44.

70. Skrzypczak M, Goryca K, Rubel T, Paziewska A, Mikula M, Jarosz D, Pachlewski J, Oledzki J, Ostrowski J. Modeling oncogenic signaling in colon tumors by multidirectional analyses of microarray data directed for maximization of analytical reliability. PLos ONE. 2010; 5:e13091: doi: 10.1371/journal.pone.0013091.

71. Chiera F, Meccia E, Degan P, Aquilina G, Pietraforte D, Minetti M, Lambeth D, Bignami M. Overexpression of human NOX1 complex induces genome instability in mammalian cells. Free Radic Biol Med. 2008; 44: 332-42.

72. Zhou R, Qian S, Gu X, Chen Z, Xiang J. Interleukin-13 and its receptors in colorectal cancer (Review). Biomed Rep. 2013; 1: 687-90.

73. Antony S, Wu Y, Hewitt SM, Anver MR, Butcher D, Jiang G, Meitzler JL, Liu H, Juhasz A, Lu J, Roy KK, Doroshow JH. Characterization of NADPH oxidase 5 expression in human tumors and tumor cell lines with a novel mouse monoclonal antibody. Free Radic Biol Med. 2013; 65: 497508 . 